\title{
Ozone Induces Nerve Growth Factor Release from Rat Tracheal Epithelial Cells during an Early Postnatal Critical Period
}

\author{
Lynnsey A. Carrell-Jacks
}

West Virginia University

Follow this and additional works at: https://researchrepository.wvu.edu/etd

\section{Recommended Citation}

Carrell-Jacks, Lynnsey A., "Ozone Induces Nerve Growth Factor Release from Rat Tracheal Epithelial Cells during an Early Postnatal Critical Period" (2011). Graduate Theses, Dissertations, and Problem Reports. 3271.

https://researchrepository.wvu.edu/etd/3271

This Thesis is protected by copyright and/or related rights. It has been brought to you by the The Research Repository @WVU with permission from the rights-holder(s). You are free to use this Thesis in any way that is permitted by the copyright and related rights legislation that applies to your use. For other uses you must obtain permission from the rights-holder(s) directly, unless additional rights are indicated by a Creative Commons license in the record and/ or on the work itself. This Thesis has been accepted for inclusion in WVU Graduate Theses, Dissertations, and Problem Reports collection by an authorized administrator of The Research Repository @ WVU. For more information, please contact researchrepository@mail.wvu.edu. 
Ozone Induces Nerve Growth Factor Release from Rat Tracheal Epithelial Cells during an Early Postnatal Critical Period

\author{
Lynnsey A. Carrell-Jacks
}

\begin{abstract}
Thesis submitted to the School of Medicine
at West Virginia University in partial fulfillment of the requirements

for the degree of
\end{abstract}

\author{
Master of Science \\ In \\ Biomedical Sciences
}
Richard D. Dey, Ph.D., Chair
Dawn D. Hunter, Ph.D.
Gregory W. Konat, Ph.D.

Department of Neurobiology and Anatomy

\author{
Morgantown, West Virginia \\ 2011
}




\title{
ABSTRACT \\ Ozone Induces Nerve Growth Factor Release from Rat Tracheal Epithelial Cells during an Early Postnatal Critical Period
}

\author{
Lynnsey A. Carrell-Jacks
}

Ozone, one of the major air pollutants in urban areas, produces epithelial cell injury and inflammation in the airways upon exposure. Previous studies have shown that ozone exposure leads to increased substance $\mathrm{P}$ (SP) expression in nerves innervating the smooth muscle in the extrapulmonary airway. Nerve growth factor (NGF), a neurotrophin, is known to increase SP expression. To determine the effect of ozone exposure on the release of NGF, a cell culture technique was developed for studying a homogenous rat tracheal epithelial cell population for analysis of NGF mRNA and protein expression. Furthermore, to determine if this effect is age-dependent, a critical period exposure paradigm was used. Rat pups exposed to ozone at postnatal day (PD) 6 showed an increase in the level of NGF mRNA while pups exposed after PD 6 showed no change in NGF expression. When rat pups exposed to ozone on PD 6 were reexposed at a later date, an increase in NGF mRNA was observed. These data suggest that exposure to ozone has an effect on NGF expression in early postnatal life and that this exposure might play a role in ozone sensitivity later in life 


\section{ACKNOWLEDGEMENTS}

I would like to express my great appreciation to all those of the Department of Neurobiology and Anatomy for their contributions to my graduate education. I would specifically like to thank my graduate advisor Dr. Richard Dey for his excellent support and guidance. I would also like to thank the members of my committee, Dr. Dawn Hunter and Dr. Gregory Konat, for their help.

I would like to give a special thanks to my colleagues- Tom Batchelor, Leor Zellner, and the Neuroscience graduate students.

In addition, I would like to acknowledge my husband, Michael, who has continually provided support during my graduate career and my daughter, Amelie, whose beautiful smile makes every day better. 


\section{TABLE OF CONTENTS}

Ozone Induces Nerve Growth Factor (NGF) Release from Rat Tracheal Epithelial Cells during an Early Postnatal Critical Period.................................................... i

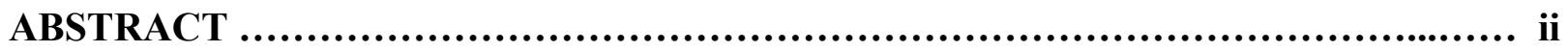

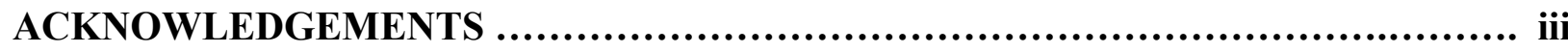

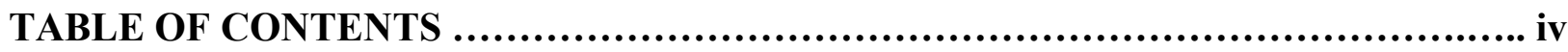

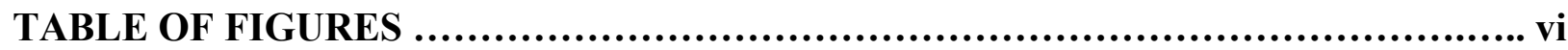

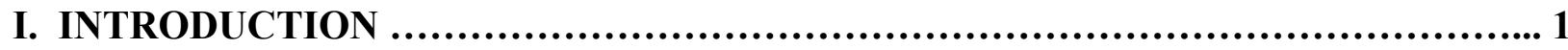

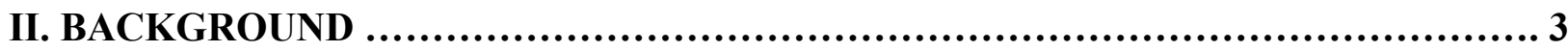

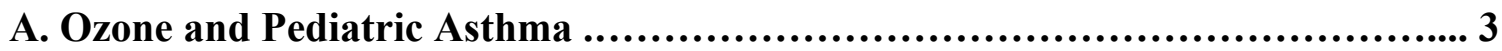

B. Tracheal Epithelial Cells .......................................................5 5

C. Nerve Growth Factor ........................................................ 5

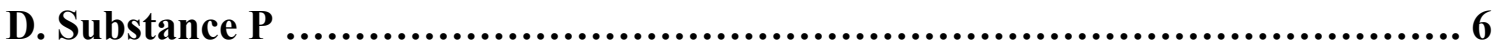

E. Statement of Problem ......................................................... 8

F. Hypothesis ….................................................................. 9

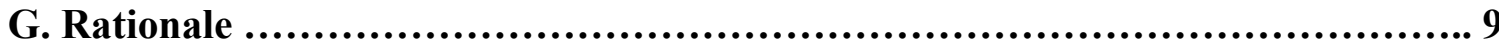

H. Specific Aims and Expected Results ........................................... 9

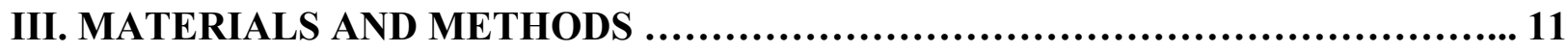

A. Animal Use and Anesthetics ................................................. 11

B. Ozone Exposure ............................................................. 11

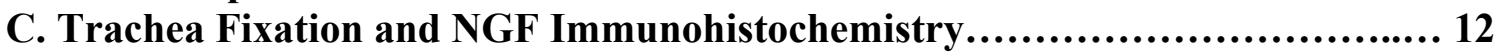

D. Tracheal Epithelial Cell Extraction............................................ 13

E. Tracheal Epithelial Cell Immunocytochemistry................................ 14

F. Trypan Blue Exclusion Assay ................................................. 15

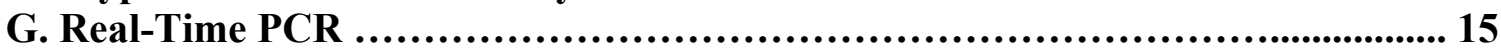

H. Rat Tracheal Epithelial Cell Protein Extraction................................. 16

I. NGF Enzyme-Linked Immunosorbent Assay................................. 16

J. Statistical Methods ........................................................... 17

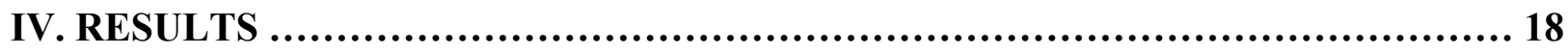

1. 1. NGF Localization in Tracheal Epithelium....................................... 18

2. Epithelial Cell Extraction ........................................................ 19

3. NGF Expression in Rat Tracheal Epithelial Cells Following Early Life $\mathrm{O}_{3}$

Exposure ........................................................................ 21 
V. DISCUSSION

VI. REFERENCE LIST ................................................................. 32

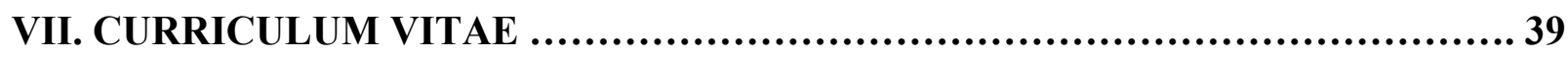

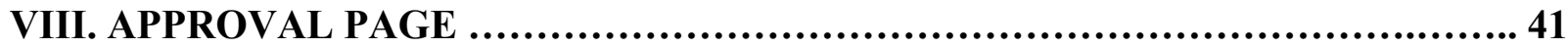




\section{TABLE OF FIGURES}

FIGURE 1. THE ROLE OF NGF IN OZONE RESPONSE. A SCHEMATIC SHOWING THE POSSIBLE ROLE OF NGF RELEASE FROM TRACHEAL EPITHELIAL CELLS IN THE REGULATION OF OZONE RESPONSE. NGF RELEASED FROM THE TRACHEAL EPITHELIAL CELLS COULD STIMULATE THE RELEASE OF SUBSTANCE P FROM THE NODOSE/JUGULAR GANGLIA AND NUCLEUS OF THE SOLITARY TRACT. SP CAN THEN STIMULATE GLAND SECRETION, EDEMA IN BLOOD VESSELS, AND SMOOTH MUSCLE CONTRACTION IN THE AIRWAY. .8

FIGURE 2. EXPERIMENTAL DESIGN SHOWING OZONE EXPOSURE PARADIGM FOR CRITICAL PERIOD STUDY. RAT PUPS WERE EXPOSED TO AIR OR OZONE INITIALLY ON PD 6 (WITHIN THE PROPOSED CRITICAL PERIOD) OR PD 21 (OUTSIDE OF THE PROPOSED CRITICAL PERIOD). THE PUPS WERE REEXPOSED TO AIR OR OZONE ON PD 28. THE ANIMALS WERE SACRIFICED 12 OR 24 HOURS AFTER THE FINAL EXPOSURE ....................................................

FIGURE 3. IMMUNOHISTOCHEMICAL STAINING SHOWING NGF IN TRACHEAL EPITHELIAL CELLS FROM PD 10 RAT PUPS EXPOSED TO EITHER AIR OR O3 (2000PPB) FOR THREE HOURS. TRACHEAS WERE ISOLATED AND FIXED USING PAF 12 OR 24 HOURS AFTER EXPOSURE. THE PRIMARY ANTIBODY WAS RABBIT ANTINGF-B MONOCLONAL (1:100). THE SECONDARY ANTIBODY WAS GOAT ANTIRABBIT ALEXA 488 (1:100). THE EPITHELIAL LAYER HAS BEEN OUTLINED IN

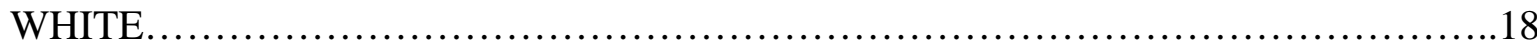

FIGURE 4. CYTOKERATIN STAINING OF CELLS ISOLATED FROM ADULT RAT TRACHEA SHOWING TRACHEAL EPITHELIAL CELLS. (A) MOUSE MONOCLONAL ANTI-PAN CYTOKERATIN; 1:100/GOAT ANTI-MOUSE FITC; 1:100. (B) NO PRIMARY CONTROL. THESE IMAGES SHOW THAT CELLS ISOLATED FROM THE TRACHEA

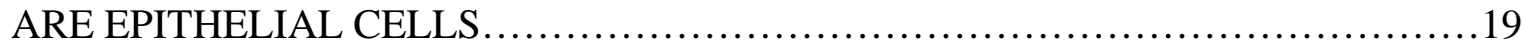

FIGURE 5. CD45 STAINING OF CELLS ISOLATED FROM ADULT RAT TRACHEA SHOWING IMMUNE CELLS (N=3 PER GROUP). MOUSE ANTI-RAT CD45;1:100/GOAT ANTI-MOUSE FITC;1:00. (A) NO IGG TREATMENT WAS USED IN THE ISOLATION OF TRACHEAL EPITHELIAL CELLS. (B) IGG TREATMENT WAS USED TO REMOVE IMMUNE CELLS FROM THE CELL CULTURE. (C) PERCENTAGE OF EPITHELIAL CELLS AS COMPARED TO IMMUNE CELLS FOR IGG AND NO IGG TREATMENTS $(\mathrm{P}<0.05)$ .20

FIGURE 6. A TRYPAN BLUE EXCLUSION ASSAY WAS USED TO DETERMINE CELL SURVIVAL FOLLOWING TRACHEAL EPITHELIAL CELL ISOLATION. OVER 99\% OF THE CELLS DID NOT SHOW TRYPAN BLUE STAINING, WHICH SUGGESTS THAT THE CELLS ARE VIABLE FOLLOWING ISOLATION. MOVING CILIATED EPITHELIAL CELLS WERE OBSERVED DURING THIS EXPERIMENT. 21 
FIGURE 7. NGF MRNA EXPRESSION RELATIVE TO B-ACTIN MRNA EXPRESSION IN PD 6 RAT PUPS 1, 6, 12, 18, AND 24 HOURS FOLLOWING EXPOSURE TO AIR OR OZONE, 2000 PPB (N=3 PER GROUP). THERE WAS A SIGNIFICANT INCREASE IN NGF MRNA EXPRESSION BETWEEN AIR AND OZONE 12 HOURS POST-EXPOSURE

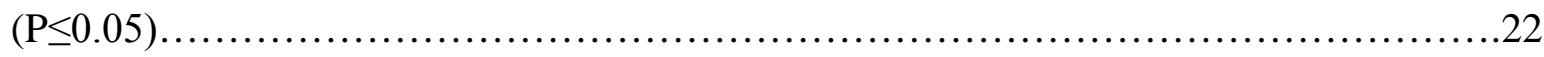

FIGURE 8. THE EFFECT OF OZONE EXPOSURE ON NGF MRNA EXPRESSION IN TRACHEAL EPITHELIAL CELLS OVER A PERIOD OF DEVELOPMENT. NGF MRNA EXPRESSION RELATIVE TO B-ACTIN MRNA EXPRESSION IN RAT PUPS EXPOSED TO AIR OR OZONE (2000 PPB) FOR THREE HOURS AND SACRIFICED 12 HOURS LATER (N=6 PER GROUP). PD 6 SHOWED A SIGNIFICANT DIFFERENCE IN NGF MRNA EXPRESSION BETWEEN AIR AND OZONE

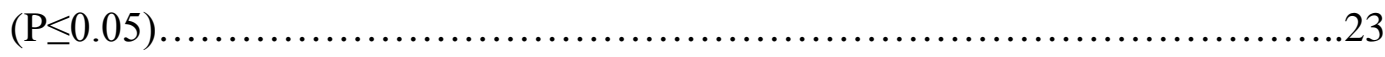

FIGURE 9. THE EFFECT OF EARLY POSTNATAL OZONE EXPOSURE ON THE AMOUNT OF NGF PROTEIN IN RAT TRACHEAL EPITHELIAL CELLS. NGF PROTEIN WAS MEASURED IN ISOLATED RAT TRACHEAL EPITHELIAL CELLS 24 HOURS AFTER EXPOSURE TO DETERMINE IF OZONE EXPOSURE (2000 PPB, 3 HOURS) HAD AN EFFECT ON THE LEVEL OF NGF IN THE CELLS. NGF PROTEIN WAS MEASURED BY ELISA. VALUES ARE MEANS $\pm \mathrm{SE}, \mathrm{N}=6$ FOR EACH GROUP AND $* \mathrm{P}<0.05$ IS SIGNIFICANT COMPARED TO AIR CONTROL....24

FIGURE 10. THE EFFECT OF OZONE (O3) EXPOSURE ON RELATIVE NGF MRNA EXPRESSION IN TRACHEAL EPITHELIAL CELLS DURING A CRITICAL PERIOD OF DEVELOPMENT. NGF WAS MEASURED TO DETERMINE IF O3 EXPOSURE (2PPM, 3HR) DURING A CRITICAL PERIOD (PD 6) WOULD RESULT IN PROLONGED CHANGES OF NGF MESSAGE UPON A SECOND O3 EXPOSURE (PD 28) IN COMPARISON TO CONTROLS AND EXPOSURES OUTSIDE THE CRITICAL PERIOD (PD 21). NGF MRNA WAS MEASURED BY REAL-TIME PCR RELATIVE TO B-ACTIN MRNA EXPRESSION. VALUES ARE MEANS \pm SE, N=6 FOR EACH GROUP AND $* \mathrm{P}<0.05$ IS SIGNIFICANT OVER ALL GROUPS, \#P<0.05 IS SIGNIFICANT OVER ALL

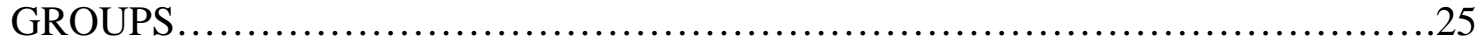




\section{INTRODUCTION}

Children are especially susceptible to airway pollutants. Early life exposure to inhaled environmental pollutants may play an important role in the pathogenesis of childhood asthma and other respiratory disorders. It has been shown that early postnatal exposure to passive cigarette smoke, allergens, and environmental pollution increases the incidence of respiratory illness and asthma later in life (Miller et al., 2009). Children are a susceptible population due to heightened sensitivity during early life and may be at risk of encountering high ozone levels while playing outside. West Virginia is ranked fourth overall for childhood asthma prevalence in the United States, with over $11 \%$ of the under-18 population suffering from asthma (Asthma Among West Virginia Children, 2006). Pediatric asthma is a national problem and a crisis in our local community.

Previous studies have shown that neurotrophin levels in the airway increase significantly following exposure to airway irritants and that this increase is followed by an upregulation of SP expression in nerves innervating the airway (Kessler \& Black, 1980; Otten et al., 1980; Schwartz et al., 1982; Wilfong \& Dey, 2004). The role of neurotrophins released from tracheal epithelial cells that might contribute to the symptoms associated with asthma is not well understood. The neuropeptide SP is considered one of the major initiators of neurogenic inflammation and airway hyperresponsiveness in asthma (Lembeck \& Holzer, 1979; Koto et al., 1995). Although tracheal epithelial cells are known to release the neurotrophins nerve growth factor (NGF) and brain derived neurotrophic factor (BDNF) and are especially sensitive to inhaled irritants (Hahn et al., 2006; Dey, et al., 1999), more work needs to be done to elucidate the possible role of airway epithelial cells in the pathogenesis of asthma. It is important to understand the role of released neurotrophins from tracheal epithelial cells in response to early postnatal ozone exposure 
because of the potential regulatory impact that neurotrophins have on airway sensory nerves, which regulate inflammatory responses associated with the pathogenesis of childhood asthma. 


\section{BACKGROUND}

\section{A. Ozone and Pediatric Asthma}

Ozone $\left(\mathrm{O}_{3}\right)$ exposures have a substantial negative impact on pulmonary health. Exposure to $\mathrm{O}_{3}$ has been shown to decrease pulmonary function (Kim et al., 2010) and increase airway inflammation (Krishna et al., 1998) in healthy subjects. The effects are more severe in sensitive subjects, such as asthmatics or smokers (Frampton et al., 1997a; Frampton et al., 1997b). The effects of $\mathrm{O}_{3}$ exposure are especially significant in children. Pediatric asthma diagnoses, attacks, hospitalizations, and deaths have increased significantly in the last two decades (Downs et al., 2001; Akinbami and Schoendorf, 2002; Babin et al., 2004). Pediatric respiratory disorders and infant mortality have been correlated to increased levels of inhaled environmental pollutants, including $\mathrm{O}_{3}$ (Loomis et al., 1999; Triche et al., 2006). Exposure of infants to $\mathrm{O}_{3}$ during development initiates drastic changes in the epithelial-mesenchymal trophic unit leading to compromised airway growth and development that persists or worsens, even without continued $\mathrm{O}_{3}$ exposure (Plopper et al., 2007). Lung function is decreased in children on days when there was a higher $\mathrm{O}_{3}$ concentration and children with physician-confirmed asthma experience the greatest decrease in lung function tests (Krzyzanowski et al., 1992; Schmitzberger et al., 1993; Lewis et al., 2005). Childhood asthma diagnoses and the prevalence of symptoms are increased in children living in areas with high ground-level $\mathrm{O}_{3}$ (Etzel et al., 2002; Sousa et al., 2009). Young children who have been diagnosed with asthma are particularly susceptible to small, short-term increases in $\mathrm{O}_{3}$ levels (Ko et al., 2007; Yamazaki et al., 2009; Dales et al., 2009) and an increase in emergency room admissions for asthma attacks has been noted on days with elevated $\mathrm{O}_{3}$ (Boutin-Forzano et al., 2004). Chronic exposure to current ambient $\mathrm{O}_{3}$ levels contributes to an increase risk of hospitalization for asthmatic children (Villeneuve et al., 2007; 
Lin et al., 2008; Moore et al., 2008), especially for children under the age of five (HernándezCadena et al., 2007). Asthmatic children using maintenance medication are particularly vulnerable to $\mathrm{O}_{3}$ (Gent et al., 2003). Furthermore, exposure to $\mathrm{O}_{3}$ reduces the bronchodilation response to short-acting $\beta$-agonist prescription medicine in children with asthma (HernándezCadena et al., 2009). These results suggest an increased susceptibility to $\mathrm{O}_{3}$ exposure in early life and childhood.

The Environmental Protection Agency is reconsidering the current national standard for ground-level $\mathrm{O}_{3}$ of $75 \mathrm{ppb}$ on the 8 hour average. However, exposure to $\mathrm{O}_{3}$ at levels far below the current national standard can be detrimental to pulmonary function. Exposure to 50ppb $\mathrm{O}_{3}$ showed substantial decreases in pulmonary function in human subjects with cumulative effects of successive exposures (Hackney et al., 1975). In both control and asthmatic subjects, exposure to $\mathrm{O}_{3}$ can cause significant increases in bronchial responsiveness and airway obstruction (Kreit et al., 1989). $\mathrm{O}_{3}$ exposure also induces inflammation in human airways, even at levels that are not significant enough to reduce pulmonary function (Koren et al., 1989; Basha et al., 1994). Blunting the airway neutrophilic inflammatory response does not prevent the functional impairment of the airways following $\mathrm{O}_{3}$ exposure (Vagaggini et al., 2001). Airway hyperresponiveness associated with $\mathrm{O}_{3}$ exposure might occur prior to the influx of neutrophils in the airway and might be dependent upon local changes (Okazawa et al., 1989). Levels at or below the current EPA standard are detrimental to human health and this study aims to explore a novel mechanism of $\mathrm{O}_{3}$-induced pulmonary damage, which will provide additional evidence that stricter standards are needed. Furthermore, the mechanism by which $\mathrm{O}_{3}$ exposure leads to a decrease in pulmonary function remains poorly understood, but it is not a result of early 
inflammatory responses (Blomberg et al., 1999). By exploring other mechanisms of action, this study will provide more information for potential clinical treatment.

\section{B. Tracheal Epithelial Cells}

Early childhood (6 to 8 years of age) is a critical period of lung development in humans (Burri, 1997). Differentiation of critical cell types and systems, among the most important being the respiratory epithelium and critical immune effector cell populations, occurs during this period (Finkelstein and Johnston, 2004). The airway epithelial cell is known to be particularly sensitive to many inhaled environmental irritants, including $\mathrm{O}_{3}$ (Bayram et al., 2002). Epithelial cells respond to $\mathrm{O}_{3}$ exposure in a series of three stages: constitutive cell activation, synthesis and release of chemotactic factors, and eosinophil or monocyte infiltration (Leikauf et al., 1995). Acute $\mathrm{O}_{3}$ exposure causes epithelial cell injury and early epithelial necrosis in terminal bronchioles and the trachea (Mustafa et al., 1990; Hyde et al., 1992; Pino et al., 1992). Activation of the NK-1 receptor during acute $\mathrm{O}_{3}$ exposure contributes to epithelial injury and subsequent epithelial proliferation, but does not influence neutrophil emigration into airways (Oslund et al., 2008). Epithelial cell injury and regeneration is greatest when $\mathrm{O}_{3}$ exposure is combined with another airway irritant, such as dust (Adamson et al., 1999) or diesel exhaust particles (Kafoury \& Kelley, 2005). $\mathrm{O}_{3}$ is thought to modulate airway responses by upregulating the release of inflammatory mediators from bronchial epithelial cells, a mechanism which may be more sensitive in asthmatic patients (Bayram et al., 2001).

\section{Nerve Growth Factor (NGF)}

Neurotrophins are believed to play a role in the pathogenesis of asthma because serum levels of nerve growth factor (NGF; Bonini et al., 1996) and brain derived neurotrophic factor (BDNF; 
Virchow et al., 2005) in serum, platelets, and plasma are significantly increased in patients with asthma. As several animal studies have shown, NGF and BDNF appear to play a part in the development of airway hyperresponsiveness (Renz et al., 2001; Bennedich et al., 2007) and in the increased sympathetic and sensory innervation of the lung (Hoyle et al., 1994). NGF and BDNF have also been shown to promote inflammation (Woolf et al., 1994) and symptoms associated with asthma (Nassenstein et al., 2003). Immune cells in the airway are thought to be particularly sensitive to the effect of neurotrophins (Nassenstein et al., 2003). Furthermore, the effect of neurotrophin release might vary across the lifespan. For instance, there is a significant decrease in the expression of the NGF high affinity TrkA in postnatal day 21 old animal compared to earlier life (Molliver and Snider, 1997). Neurotrophins in the airway are released from many cell types, including inflammatory cells in the bronchial mucosa, fibroblasts, smooth muscle cells, and airway epithelial cells (Freund \& Frossard, 2004). In the inflamed lung, airway epithelial cells are a major contributor of NGF and BDNF (Hahn et al., 2006). This study will examine the effect of $\mathrm{O}_{3}$ exposure on NGF production in a pure population of tracheal epithelial cells.

\section{Substance P (SP)}

NGF is known to stimulate SP expression in sensory neurons (Miller et al., 1992) and is necessary for SP production and neuronal survival in vitro (Adler et al., 1984). SP immunoreactive nerve fibers are increased in tracheal smooth muscle in cultured trachea treated with NGF (Wu and Dey, 2006). SP immunoreactive nerve fibers are also increased in the airways of asthmatic subjects (Ollerenshaw et al., 1991). The airway hyperresponsiveness associated with $\mathrm{O}_{3}$ exposure is thought to be the result of SP-enhanced acetylcholine release (Wu et al., 1997). SP appears to be released in response to stimulation of primary afferent C-fibers 
(Barnes, 2001; Budai and Larson, 1995). SP is increased in lung homogenates and in nerve fibers innervating the airway following allergen challenge (Fischer et al., 1996) and $\mathrm{O}_{3}$ exposure (Wu et al., 2007; Dey et al., 2009). SP potentially plays a role in the development of neurogenic inflammation (Hsiue et al., 1992; Donkin et al., 2007). $\mathrm{O}_{3}$ exposure increases the release of SP, suggesting that the mode of action of $\mathrm{O}_{3}$ results in increased activity of airway sensory nerves followed by an increase in the release of neuropeptides (Schierhor et al., 2002). Depletion of Cfibers reduces the effect of $\mathrm{O}_{3}$ on increased responsiveness, confirming that $\mathrm{O}_{3}$ increases reactivity in part through the local effects of C-fibers (Joad et al., 1996). The release of SP from sensory nerves can lead to airway submucosal glands mucus secretion (Khansaheb et al., 2010), microvascular leakage, and bronchoconstriction (Lundberg et al., 1983; Tokuyama et al., 1993) (See Figure 1). 


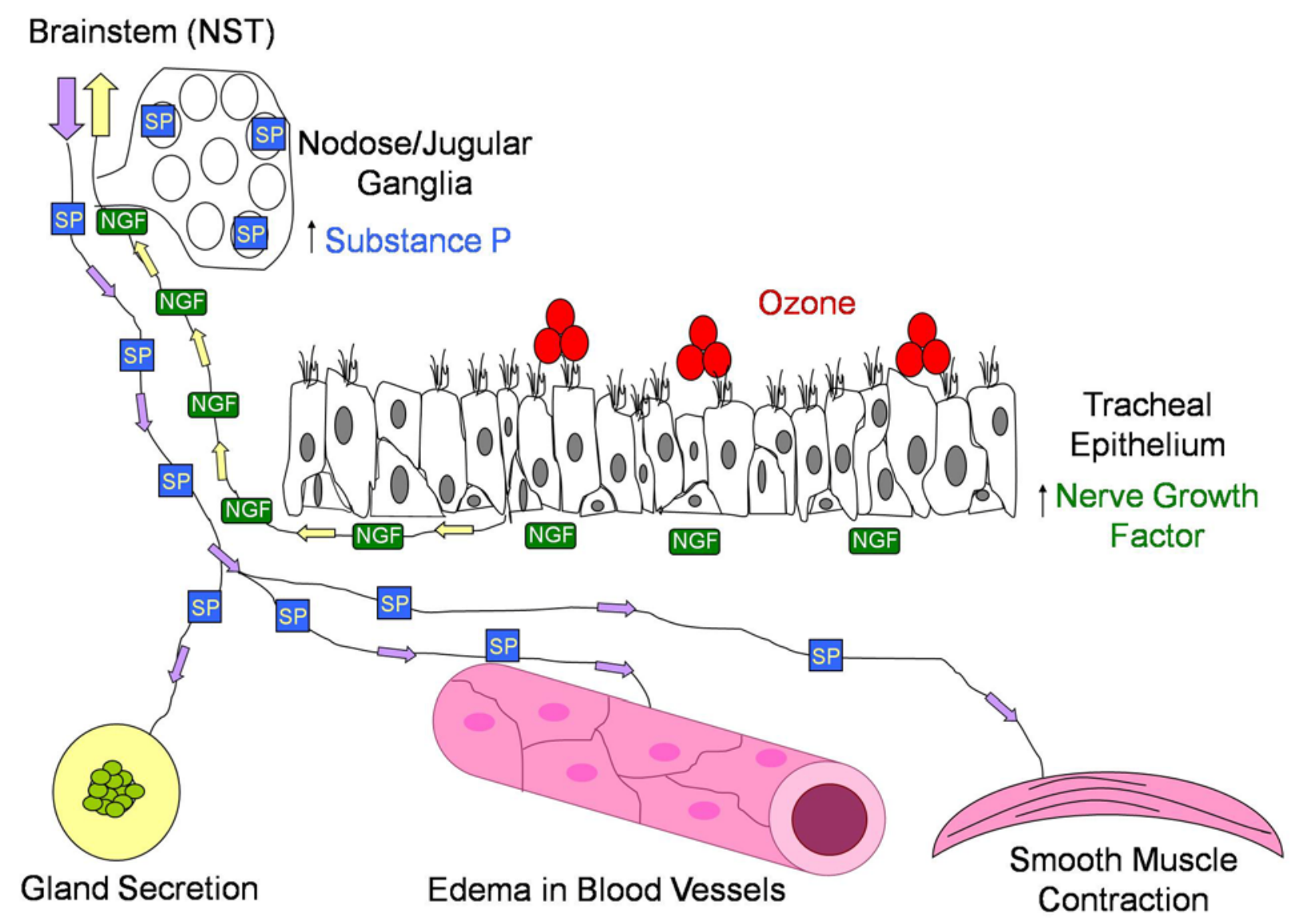

Figure 1. The Role of NGF in $\mathrm{O}_{3}$ Response. A schematic showing the possible role of NGF release from tracheal epithelial cells in the regulation of $\mathrm{O}_{3}$ response. NGF released from the tracheal epithelial cells could stimulate the release of Substance P from the Nodose/Jugular ganglia and nucleus of the solitary tract. SP can then stimulate gland secretion, edema in blood vessels, and smooth muscle contraction in the airway.

\section{E. Statement of Problem}

When combined, these results suggest an increased sensitivity to $\mathrm{O}_{3}$ exposure at early postnatal ages leads to an increase in asthma diagnoses and symptoms in part due to SP expression and subsequent neurogenic inflammation. Neurotrophins are known to regulate the expression of SP in airway nerves, particularly those innervating the smooth muscle and blood vessels, which are sites of airway responsiveness and airway inflammation, respectively. 
Epithelial cells, which are adjacent to the smooth muscle in the trachea, are the first cells contacted by inhaled $\mathrm{O}_{3}$ in the airway and one of the major contributors of neurotrophins in the challenged airway. Because NGF is increased in patients diagnosed with asthma and subjects exposed to $\mathrm{O}_{3}$, it is possible that the early life sensitivity to $\mathrm{O}_{3}$ exposure could be due to changes in the immediate release of neurotrophins from tracheal epithelial cells.

\section{F. Hypothesis}

The central hypothesis of this study is that exposure to O3 will cause an increase in NGF production in rat tracheal epithelial cells. Furthermore, this increase will be age-dependent, such that $\mathrm{O}_{3}$ exposure at an earlier postnatal day will lead to an increase in neurotrophins while a later exposure will not. Finally, this study hypothesizes that an $\mathrm{O}_{3}$ exposure during the proposed critical period will increase sensitivity to later $\mathrm{O}_{3}$ exposures that occur outside of the proposed critical period.

\section{G. Rationale}

Previous studies have shown that SP NFD increases in the airway following an early postnatal $\mathrm{O}_{3}$ exposure. Knowing where the neurotrophins that guide this process are being produced could lead to interventions that eliminate or reduce the response to $\mathrm{O}_{3}$.

\section{H. Specific Aims}

1. Determine the effect of an early postnatal $\mathrm{O}_{3}$ exposure on the release of NGF from tracheal epithelial cells in an in vivo rat model.

2. Define a sensitive period of development during which an exposure to $\mathrm{O}_{3}$ has an effect on the production of NGF. 
3. Examine the effect an $\mathrm{O}_{3}$ exposure during the proposed critical period has on later exposures to $\mathrm{O}_{3}$ outside of the critical period. 


\section{MATERIALS AND METHODS}

\section{A. Animal Use and Anesthetics}

Pregnant, late gestation Fischer 344 rats (Harlan Laboratories, Inc) were housed one per cage, under controlled light-cycle (12 hr. light/12 hr. dark) and temperature (22-24 $\left.{ }^{\circ} \mathrm{C}\right)$ conditions, with access to food and water ad libitum in the West Virginia University animal facility. Rat pups were housed with their dam until sacrificed. Animals were sacrificed 12 or 24 hours after $\mathrm{O}_{3}$ /air exposure with a lethal intraperitoneal injection of sodium pentobarbital (Nembutal, 200 mg/kg). All procedures were approved through ACUC review under Protocol \#10-0401.

\section{B. $\mathrm{O}_{3}$ Exposure}

All in vivo $\mathrm{O}_{3}$ exposures were done at $2000 \mathrm{ppb}$ in a $12 \mathrm{x} 12$ inch stainless steel and glass chamber for 3 hours. $\mathrm{O}_{3}$ was produced by passing hospital-grade air through a drying and highefficiency particle (HEPA) filter and then through an ultraviolet light source. The $\mathrm{O}_{3}$ concentration in the chamber was measured by chemiluminescence with a calibrated $\mathrm{O}_{3}$ analyzer (OA 350-2R model; Forney Corporation; Carrolton, TX). Air control animals were exposed to filtered air using procedures identical to those above, except $\mathrm{O}_{3}$ was not delivered to the mixing chamber. The $\mathrm{O}_{3}$ exposure apparatus has been described in detail elsewhere (Wu et al., 2002).

Rat pups were removed from their mother and exposed to $\mathrm{O}_{3} /$ air on postnatal day (PD) 6, $10,15,21$, or 28 . In some experiments, animals were exposed to $\mathrm{O}_{3}$ /air twice to determine the effect of an early postnatal exposure (PD 6) on a second exposure outside of the critical period window (PD 28). See Figure 2 for the critical period experimental design. 
iltered Air

O3: $3 \mathrm{hr}, 2 \mathrm{ppm}$

Sacrifice

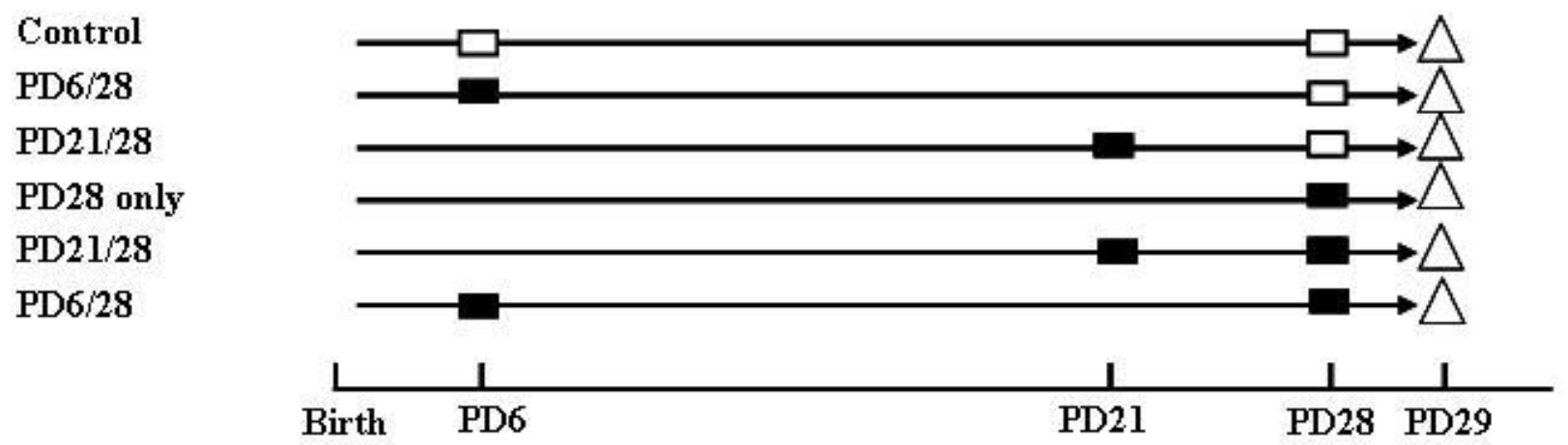

Figure 2. Experimental design showing $\mathrm{O}_{3}$ exposure paradigm for critical period study. Rat pups were exposed to air or $\mathrm{O}_{3}$ initially on PD 6 (within the proposed critical period) or PD 21 (outside of the proposed critical period). The pups were reexposed to air or $\mathrm{O}_{3}$ on PD 28. The animals were sacrificed 12 or 24 hours after the final exposure.

\section{Trachea Fixation and NGF Immunohistochemistry}

Immunohistochemical staining was used to determine NGF presence in the airway epithelium. Twelve or twenty-four hours after exposure, the tracheas were fixed with picric acidformaldehyde for three hours. The tracheas were rinsed twice with a $0.1 \mathrm{M}$ phosphate-buffered saline containing $0.15 \%$ Triton X-100 (PBS-Tx, pH 7.8) and remained in PBS-Tx overnight at $4^{\circ} \mathrm{C}$. The next day, the tracheas were placed on corks, covered with Tissue Tek O.C.T. compound (Sakura, Torrance, CA), frozen in isopentane cooled with liquid nitrogen, and stored in airtight plastic bags at $-80^{\circ} \mathrm{C}$.

Cryostat sections (12 $\mu$ m thick) of airway tissue were collected on gelatin-coated cover slips and dried briefly at room temperature. The sections were incubated with rabbit anti-NGF- $\beta$ monoclonal (1:100) primary antiserum diluted in PBS-Tx $+1 \%$ bovine serum albumin (BSA) (PBS-Tx-BSA, pH 7.8) at $4^{\circ} \mathrm{C}$ overnight. The sections were rinsed three times for 5 minutes 
each with PBS-Tx-BSA, covered with goat anti-rabbit Alexa 488 (1:100) in PBS-Tx-BSA, incubated at $37^{\circ} \mathrm{C}$ for 30 minutes, rinsed three times for 5 minutes each in PBS-Tx-BSA and mounted on glass slides in Fluoromount (Southern Biotechnology, Birmingham, AL). The sections were observed using an Olympus AX70 fluorescence microscope equipped with a fluorescein filter (excitation $495 \mathrm{~nm}$ and emission $520 \mathrm{~nm}$ ). Controls consisted of testing the specificity of primary antiserum by absorption with $1 \mu \mathrm{g} / \mathrm{ml}$ of the specific antigen. Nonspecific background labeling was determined by omission of primary antiserum. Sections of airways were observed (40X magnification) on a Zeiss LSM 510 confocal microscope equipped with an argon laser (excitation 495 nm and emission 520 nm, Zeiss, Oberkochen, Germany).

\section{Tracheal Epithelial Cell Extraction}

Tracheas were excised and immersed in ice cold Hank’s Buffered Salt Solution (HBSS) while excess tissue was removed. Next, the tracheas were placed in $10 \mathrm{~mL}$ of pre-warmed $\left(37^{\circ} \mathrm{C}\right)$ dissociation medium (0.5\% protease in Dulbecco’s Modified Eagle Medium (DMEM)F12/5\%Pen-Strep) and incubated at $37^{\circ} \mathrm{C}$ with agitation for 1 hour. Fetal bovine serum (1ml, FBS) was added to the stop the protease digestion and the tissues was removed and rinsed in 10 mL of culture medium (5\% FBS and 4\% DNase I in DMEM-F12/5\%Pen-Strep). The tracheal pieces were discarded and the culture and dissociation media cell suspensions were pooled. The cell suspension was incubated on anti-IgG antibody coated $100 \mathrm{~mm}$ dishes at $37^{\circ} \mathrm{C}$ for 1 hour to remove immune cells, predominately neutrophils. The cell suspension was decanted and the cells were collected by centrifugation (1,000 rpm/10 minutes). 


\section{E. Tracheal Epithelial Cell Immunocytochemistry}

To determine the efficiency of the tracheal epithelial cell extraction, immunocytochemistry was performed. Epithelial cells were extracted from adult rats exposed to $\mathrm{O}_{3}(2000 \mathrm{ppb})$ for three hours. The density of the extracted cell population was calculated and the appropriate amount of suspension was placed on a subbed slip using a cytospin (400 rpm for four minutes). The slips were dried at room temperature for 30 minutes and placed in a prechilled 1:1 methanol/acetone solution for 10 minutes at $-20^{\circ} \mathrm{C}$. The slips were dried at room temperature for two minutes and the primary antibody was added. The slips were incubated at $4^{\circ} \mathrm{C}$ overnight and washed three times for 5 minutes each in PBS-Tx-BSA. The secondary antibody was added and the slips were incubated at $37^{\circ} \mathrm{C}$ for 30 minutes. After incubation the slips were washed three times for 5 minutes each in PBS-Tx-BSA and mounted on slides using Flouromount-G. Slides were analyzed (40X magnification) by a Zeiss LSM 510 confocal microscope equipped with an argon laser (excitation $495 \mathrm{~nm}$ and emission $520 \mathrm{~nm}$, Zeiss, Oberkochen, Germany). To confirm that the cells in the population were epithelial cells, the primary antibody used was mouse monoclonal anti-Pan cytokeratin (1:100) with a secondary goat anti-mouse FITC (1:100) antibody. To determine the population of immune cells in the extracted suspension, cells that were treated with IgG antibody coated plates were compared to cells that were not treated with the IgG antibody coated plates. The primary antibody was mouse anti-rat CD45 antibody (1:100) and the secondary antibody was goat anti-mouse FITCconjugated antibody (1:100). The number of total cells and immune positive cells were counted by two independent researchers. 


\section{F. Trypan Blue Exclusion Assay}

A Trypan Blue Exclusion Assay was used to determine the viability of the cells following tracheal epithelial cell extraction. The cell density of the cell suspension was determined using a hemacytometer. Immediately following cell extraction and purification, $0.1 \mathrm{~mL}$ of $0.4 \%$ trypan blue in PBS was added to $1 \mathrm{~mL}$ of cell suspension. The cell suspension was loaded on a hemacytometer and examined under a microscope at low magnification. The number of blue stained cells and the number of total cells were counted.

\section{G. Real-Time PCR}

Total RNA was extracted from the cells according to the manufacturer's instructions (RNeasy Plus Micro Kit, Qiagen,Valencia, CA). Briefly, cells were lysed and homogenized in a buffer that inactivates RNases. The lysate was passed through a gDNA eliminator column to reduce the risk of genomic DNA contamination. Ethanol was added to the flow-through to promote RNA binding and total RNA was bound by passing the sample through an RNeasy MinElute spin column. Contaminants were washed away and the RNA was eluted in RNase free water. A Nanodrop was used to measure the purity and concentration of the RNA in the sample by determining A260/A280. Total RNA was transcribed into cDNA using the High Capacity cDNA Kit (Applied Biosystems, Foster City, CA) according to the manufacturer’s instructions. The cDNA was then amplified in the 7500 RT-PCR System using the NGF Taq Man gene expression assays (Applied Biosystems). The Relative Quantification Method (2- $\Delta \Delta \mathrm{Ct}$ ) was used to determine the NGF mRNA levels. NGF expression levels were normalized using $\beta$-actin expression as an internal control. 


\section{H. Rat Tracheal Epithelial Cell Protein Extraction}

Following rat tracheal epithelial cell isolation, the cells were washed twice in ice cold PBS. The cell extraction buffer was supplemented with $1 \mathrm{mM}$ PMSF and protease inhibitor cocktail (Sigma) added just before use. The supernatant was removed and discarded. The cells were lysed in $250 \mu \mathrm{L}$ of Cell Extraction Buffer (Invitrogen) for 30 minutes, on ice, with vortexing for 1 minute at 10 minute intervals. The extract was transferred to microcentrifuge tubes and centrifuged at $13,000 \mathrm{rpm}$ for 10 minutes at $4^{\circ} \mathrm{C}$. The clear lysate was at $-80^{\circ} \mathrm{C}$ until ready for assay. The total protein level was measured using a nanodrop and was controlled for each sample in the ELISA

\section{NGF Enzyme-Linked Immunoassay}

The concentration of NGF was assayed using the NGF Emax ImmunoAssay System (Promega, Madison, WI). NGF was detected using an antibody sandwich format in 96 well plates (Figure 2). Each well was initially coated with $100 \mu \mathrm{l}$ of anti-NGF pAb and incubated overnight followed by 1 hour incubation with blocking buffer ( $200 \mu \mathrm{l} /$ well) to prevent nonspecific binding. Either $100 \mu \mathrm{l}$ of cell lysate or $100 \mu \mathrm{l}$ of NGF standard (7.8-1000 pg/ml) was

added to each well. The plate was incubated for 6 hours with agitation followed by an overnight incubation with anti-NGF mAb (100 $\mu \mathrm{l} /$ well). For color development an anti-rat IgG, horseradish peroxidase conjugate antibody was added to each well (100 $\mu \mathrm{l})$ followed by TMB solution, which reacts with the peroxidase-labeled conjugates. The reaction was stopped after 10 minutes with $1 \mathrm{~N}$ hydrochloric acid $(100 \mu \mathrm{l} /$ well). The absorbance of each well was measured at $450 \mathrm{~nm}$ on a Spectra Max 340pc plate reader (Molecular Devices, Sunnyvale, CA). The concentration of NGF in each lysate sample was calculated from a standard curve. All samples 
were run in duplicate, and as a negative control, a cell extraction buffer sample was run with each assay.

\section{J. Statistical Methods}

Differences between groups were determined using a two-tailed Student's T-Test using Microsoft Excel software. Animals exposed to O3 were compared to age or time matched air exposed controls. In the critical period experiment, an ANOVA was performed to compare each group to all other groups. In all studies, a p-value less than or equal to 0.05 was considered significantly different. Mean and standard error is reported for each value. 


\section{Results}

\section{NGF Localization in Tracheal Epithelium}

A series of experiments was conducted to first determine if NGF is present in rat pup tracheal epithelial cells and to validate the tracheal epithelial cell extraction technique. Rat pups were exposed to air or $\mathrm{O}_{3}(2000 \mathrm{ppb})$ for 3 hours and sacrificed 12 or 24 hours after exposure. The tracheas were fixed, frozen, and sectioned onto cover slips. The sections were treated with rabbit anti-NGF- $\beta$ monoclonal (1:100) and goat anti-rabbit Alexa 488 (1:100). When viewed under a confocal microscope, NGF fluorescence was observed in the tracheal epithelial layer (see Figure 3). Other studies have also shown that NGF is located in tracheal epithelial cells (Hahn et al., 2006; Pons et al., 2001; Fox et al., 2001).

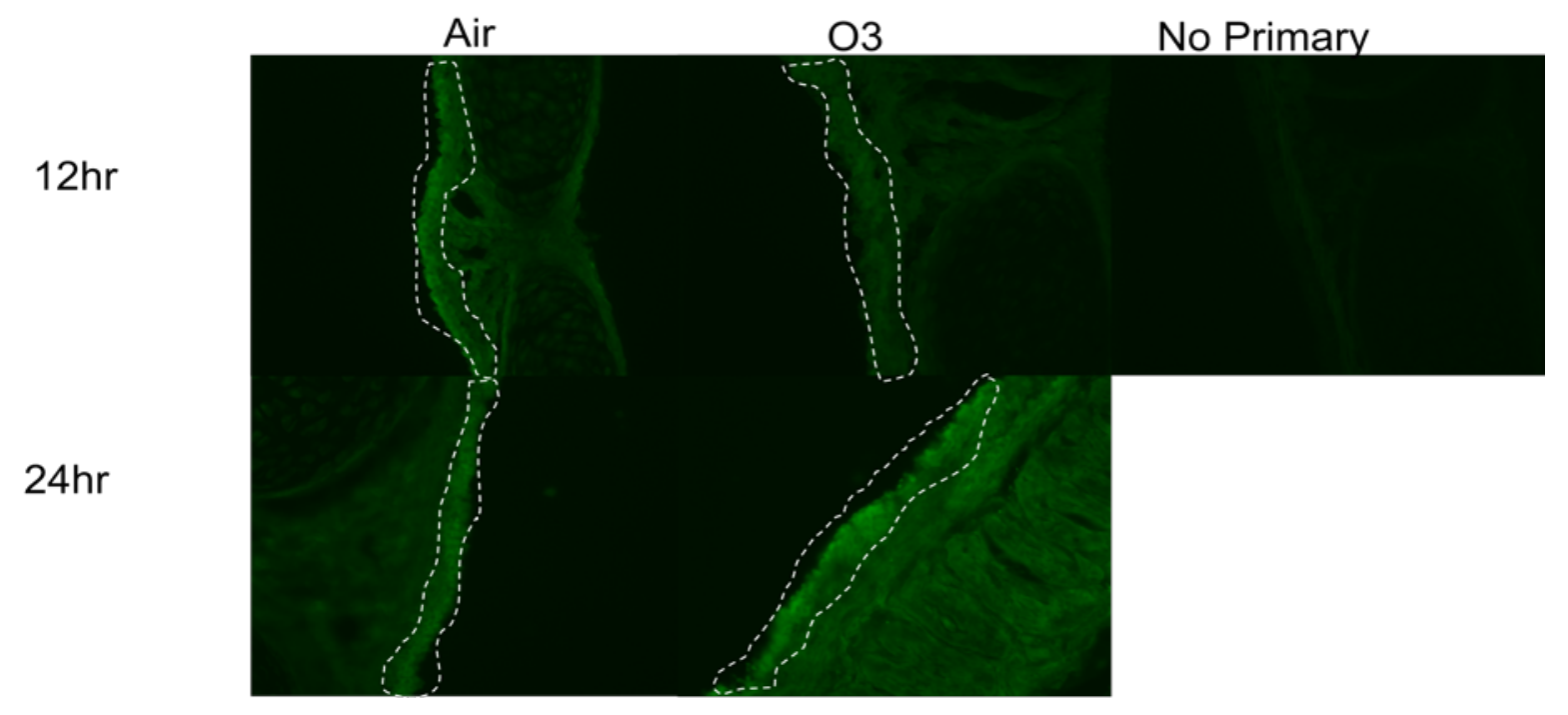

Figure 3. Immunohistochemical staining showing NGF in tracheal epithelial cells from PD 10 rat pups exposed to either air or $\mathrm{O}_{3}(2000 \mathrm{ppb})$ for three hours. Tracheas were isolated and fixed using PAF 12 or 24 hours after exposure. The primary antibody was rabbit anti-NGF- $\beta$ monoclonal (1:100). The secondary antibody was goat anti-rabbit Alexa 488 (1:100). The epithelial layer has been outlined in white. 


\section{Epithelial Cell Extraction}

To test the validity of the cell extraction technique, adult Fisher 344 female rats were exposed to $\mathrm{O}_{3}$ (2000 ppb) for 3 hours and sacrificed 24 hours later. The tracheal epithelial cells were extracted as described and cytospins of the cells were collected on glass slides. The cells were stained with mouse monoclonal anti-pan cytokeratin (1:100) and a goat anti-mouse FITC secondary (1:100) and imaged under a confocal microscope. Fluorescence was observed in the cell population, confirming the presence of epithelial cells. A control sample that was treated with the secondary antibody only showed no staining. (See Figure 4).

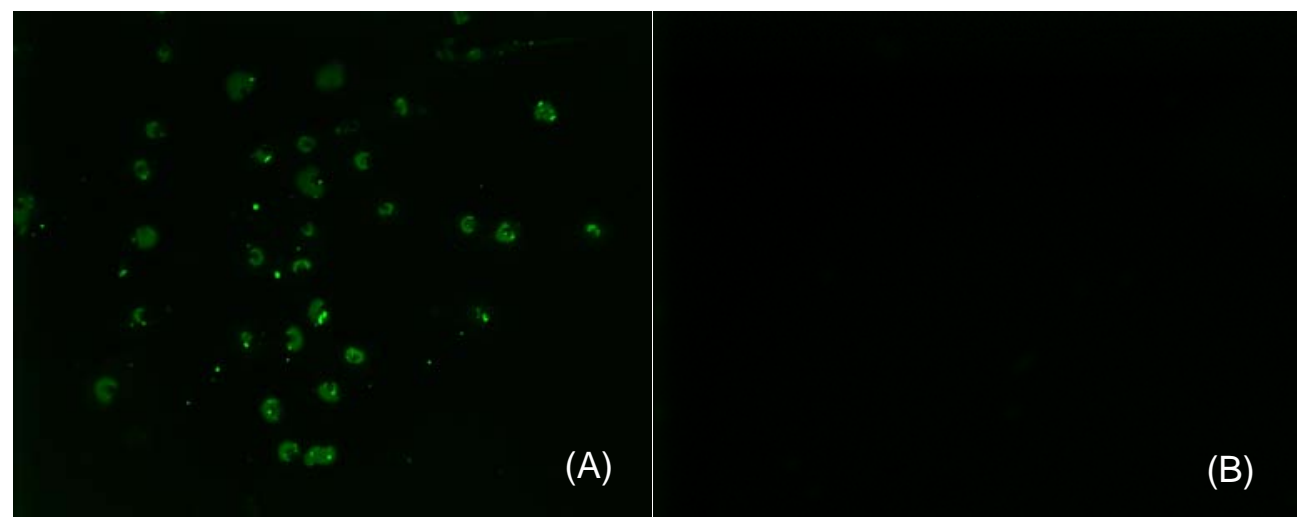

Figure 4. Cytokeratin staining of cells isolated from adult rat trachea showing tracheal epithelial cells. (A) Mouse Monoclonal anti-Pan Cytokeratin; 1:100/Goat anti-Mouse FITC; 1:100. (B) No primary control. These images show that cells isolated from the trachea are epithelial cells.

The treatment of the cells with an anti-IgG antibody was tested to determine the effect this treatment had on the population of immune cells in the cell culture. The cells extracted from adult Fisher 344 female rats that were treated with $\mathrm{O}_{3}$ were either plated on tissue culture treated plates with an anti-IgG antibody or were plated on plates that had no antibody for one hour. The purpose of this procedure is to remove immune cells from the population by adherence to the antibody on the plate. Cells that were plated with anti-IgG antibody showed a reduction in the number of immune cells in the final population count (See Figure 5). The population that was 
treated with the antibody was $96.0 \%( \pm 1.02632 \%)$ pure epithelial cells, while the population that was not treated was 93.8\% (0.49497\%) pure epithelial cells ( $\mathrm{p} \leq 0.05$; Figure $5 \mathrm{c})$.
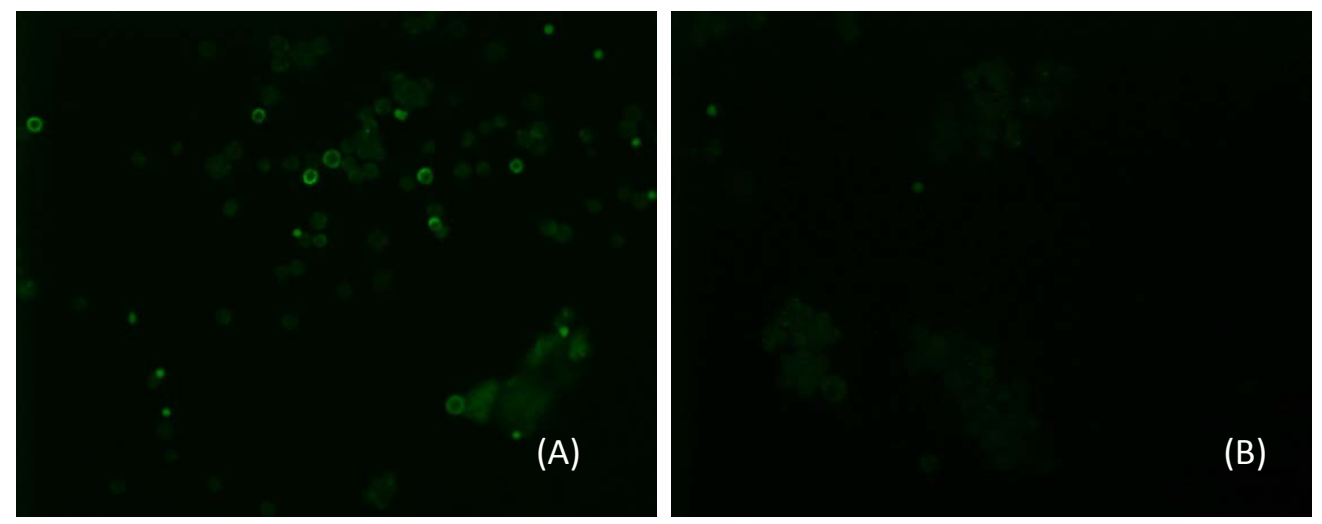

(C)

Percentage of Epithelial Cells by IgG Treatment

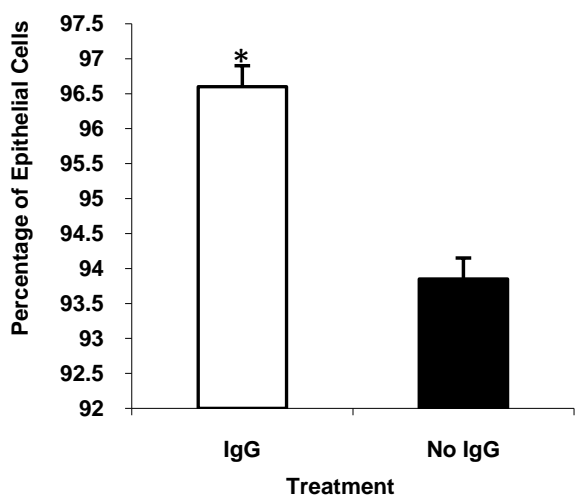

Figure 5. CD45 staining of cells isolated from adult rat trachea showing immune cells ( $\mathrm{n}=3$ per group). Mouse anti-Rat CD45;1:100/Goat anti-Mouse FITC;1:00. (A) No IgG treatment was used in the isolation of tracheal epithelial cells. (B) IgG treatment was used to remove immune cells from the cell culture. (C) Percentage of epithelial cells as compared to immune cells for IgG and no IgG treatments $(\mathrm{p}<0.05)$. Values are means $\square \square \mathrm{SE}, \mathrm{n}=3$ for each group ari $\mathrm{p}<0.05$ is significant.

Finally, a Trypan Blue Exclusion Assay was performed on extracted cells to determine the viability of cells that have been through the extraction procedure. The purpose of this experiment was to evaluate the potential degradation of RNA during the extraction process, as 
compromised cells will take up the blue staining. The cells were treated with Trypan Blue and viewed on a hemocytometer. The number of total cells and the cells that took up the dye were counted. Less than $1 \%$ of cells showed Trypan Blue staining (see Figure 6). Beating ciliated epithelial cells were also observed in this experiment.

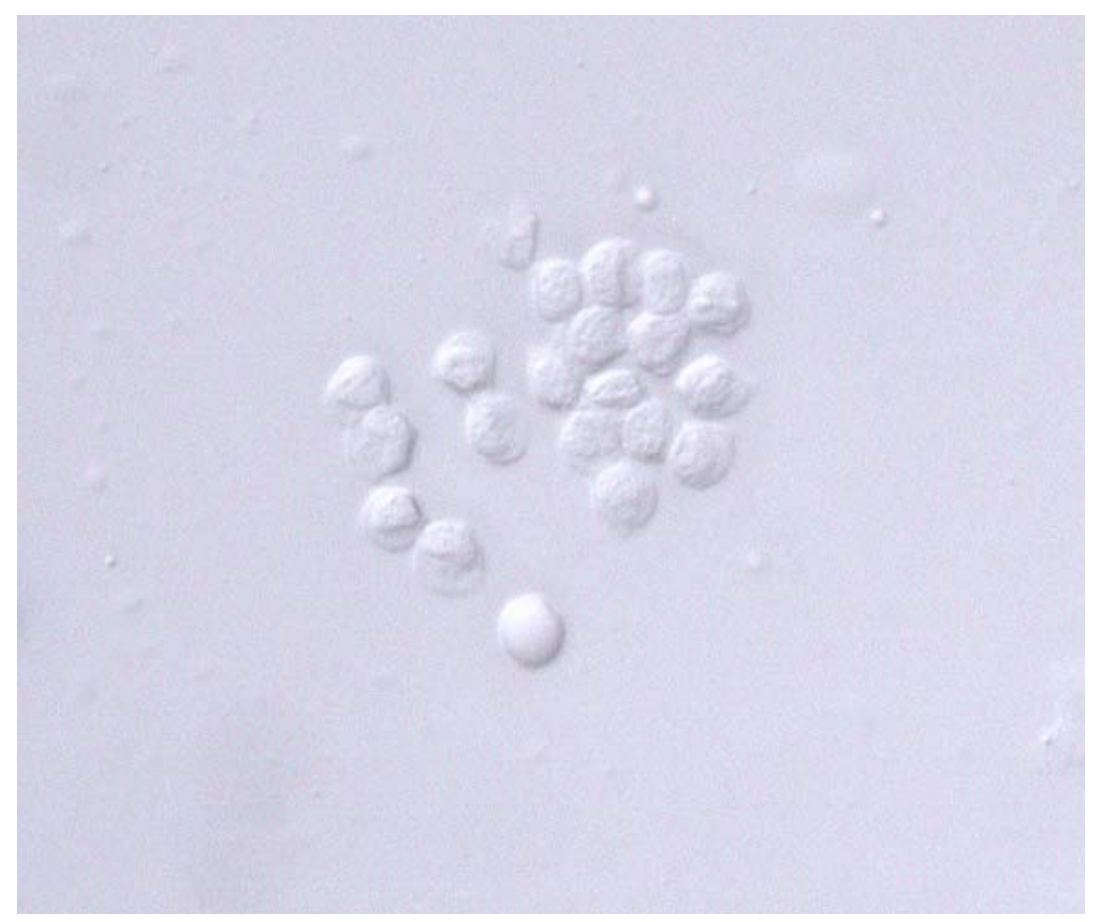

Figure 6. A Trypan Blue exclusion assay was used to determine cell survival following tracheal epithelial cell isolation. Over 99\% of the cells did not show Trypan Blue staining, which suggests that the cells are viable following isolation. Moving ciliated epithelial cells were observed during this experiment.

\section{NGF Expression in Rat Tracheal Epithelial Cells Following Early Life $\mathrm{O}_{3}$ Exposure}

Rat pups were exposed to either air or $\mathrm{O}_{3}(2000 \mathrm{ppb})$ for three hours. The rat pups were sacrificed 1, 6, 12, 18, or 24 hours after exposure. The tracheal epithelial cells were extracted and total RNA was collected and transcribed into cDNA. RT-PCR was performed using an NGF Taq man assay. Rat pups exposed to $\mathrm{O}_{3}$ and sacrificed 12 hours later showed a significant increase in the amount of NGF mRNA ( $2.24 \pm 0.35)$ compared to air controls $(1 \pm 0.252, \mathrm{p} \leq 0.05)$. Each 
integer represents a fold change in the level of NGF mRNA. Significant differences in the level of NGF mRNA were not observed at any other time point following exposure. (See Figure 7).

\section{Relative NGF mRNA Expression Across Time Post- Exposure}

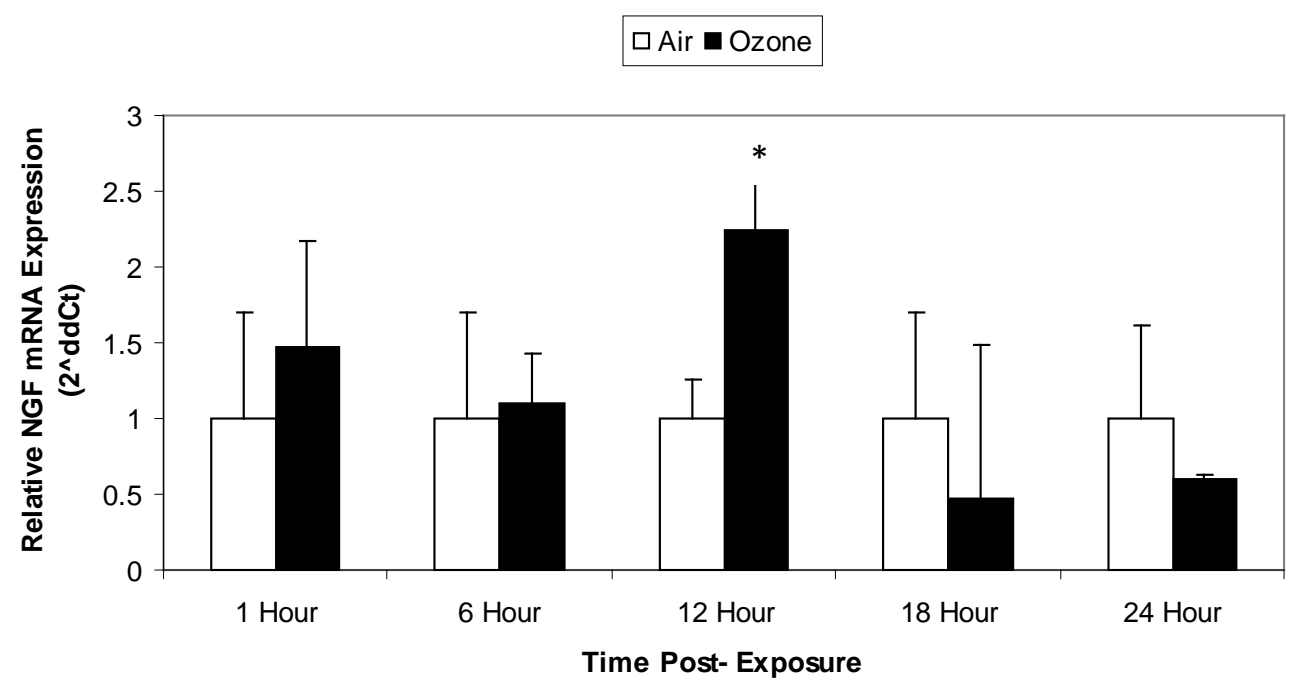

Figure 7. NGF mRNA expression relative to $\beta$-actin mRNA expression in PD 6 rat pups 1,6 , 12,18 , and 24 hours following exposure to air or $\mathrm{O}_{3}, 2000 \mathrm{ppb}$ (n=3 per group). There was a significant increase in NGF mRNA expression between air and $\mathrm{O}_{3} 12$ hours post-exposure $(\mathrm{p} \leq 0.05)$. Values are means $\pm S E, n=3$ for each group and $* p<0.05$ is significant.

To determine the effect of age at exposure on the level of NGF mRNA in tracheal epithelial cells, rat pups were exposed to air or $\mathrm{O}_{3}(2000 \mathrm{ppb})$ on PD 6, 10, 15, 21, or 28 for 3 hours and sacrificed 12 hours later. The level of NGF mRNA was measured as in the previous experiment. No significant changes were observed at any other age point. A substantial increase in the total level of NGF mRNA was observed at PD 10 and PD 15 relative to all other ages for both air and $\mathrm{O}_{3}$ exposed animals. (See Figure 8). 
Relative NGF mRNA Expression in Development

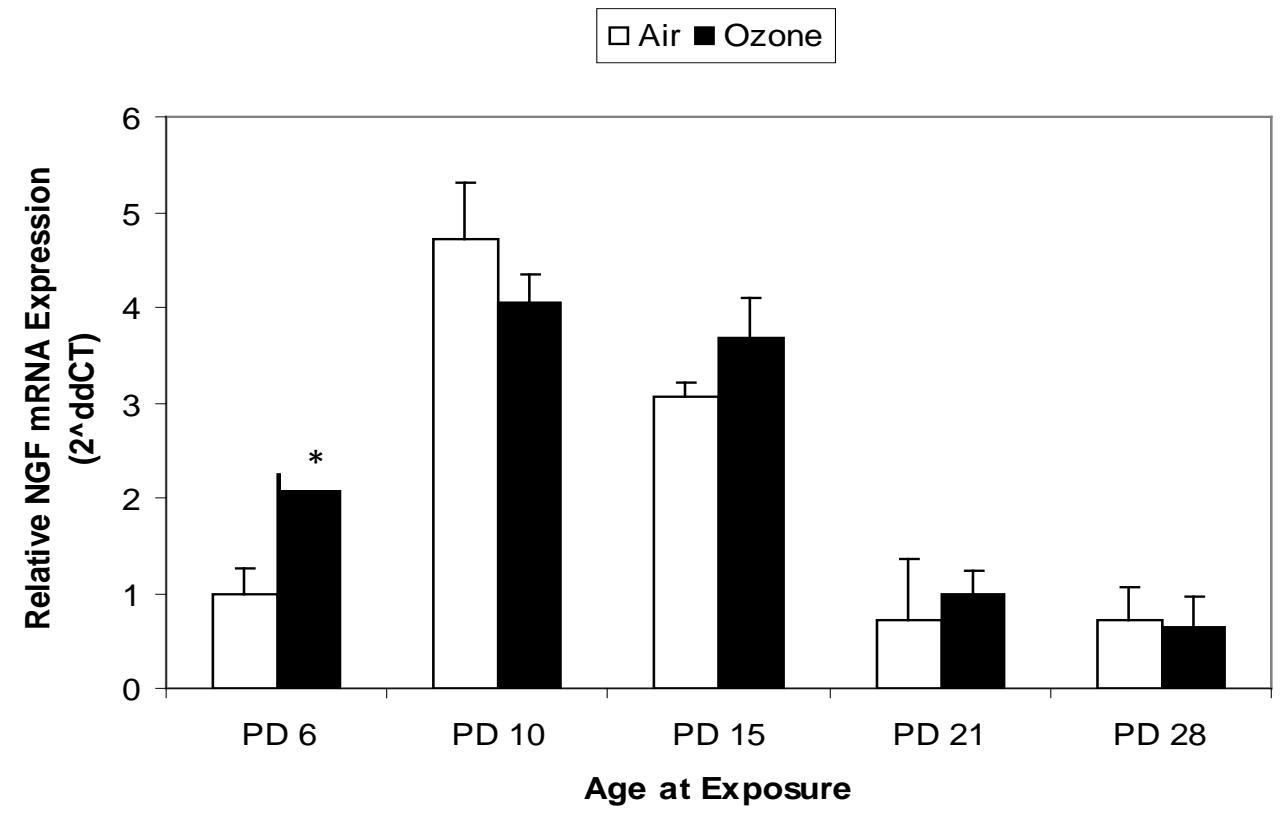

Figure 8. The effect of $\mathrm{O}_{3}$ exposure on NGF mRNA expression in tracheal epithelial cells over a period of development. NGF mRNA expression relative to $\beta$-actin mRNA expression in rat pups exposed to air or $\mathrm{O}_{3}(2000 \mathrm{ppb})$ for three hours and sacrificed 12 hours later. PD 6 showed a significant difference in NGF mRNA expression between air and $\mathrm{O}_{3}(\mathrm{p} \leq 0.05)$. Values are means $\pm \mathrm{SE}, \mathrm{n}=6$ for each group and ${ }^{*} \mathrm{p}<0.05$ is significant.

The amount of NGF protein in the isolated rat tracheal epithelial cells was also measured using ELISA to determine the effect of an early postnatal $\mathrm{O}_{3}$ exposure. NGF protein level was not significantly different from air controls for animals exposed on PD 6, PD 10, or PD 28. NGF protein was significantly different for rat pups exposed on PD $15(34.11642 \pm 6.075263$ pg/mL) compared to air control $(17.78675 \pm 2.396285 \mathrm{pg} / \mathrm{mL})$ and for PD 21 (49.57736 \pm 5.933555 $\mathrm{pg} / \mathrm{mL})$ compared to control (18.1799 $\pm 6.962812 \mathrm{pg} / \mathrm{mL}), \mathrm{p} \leq 0.05$. 


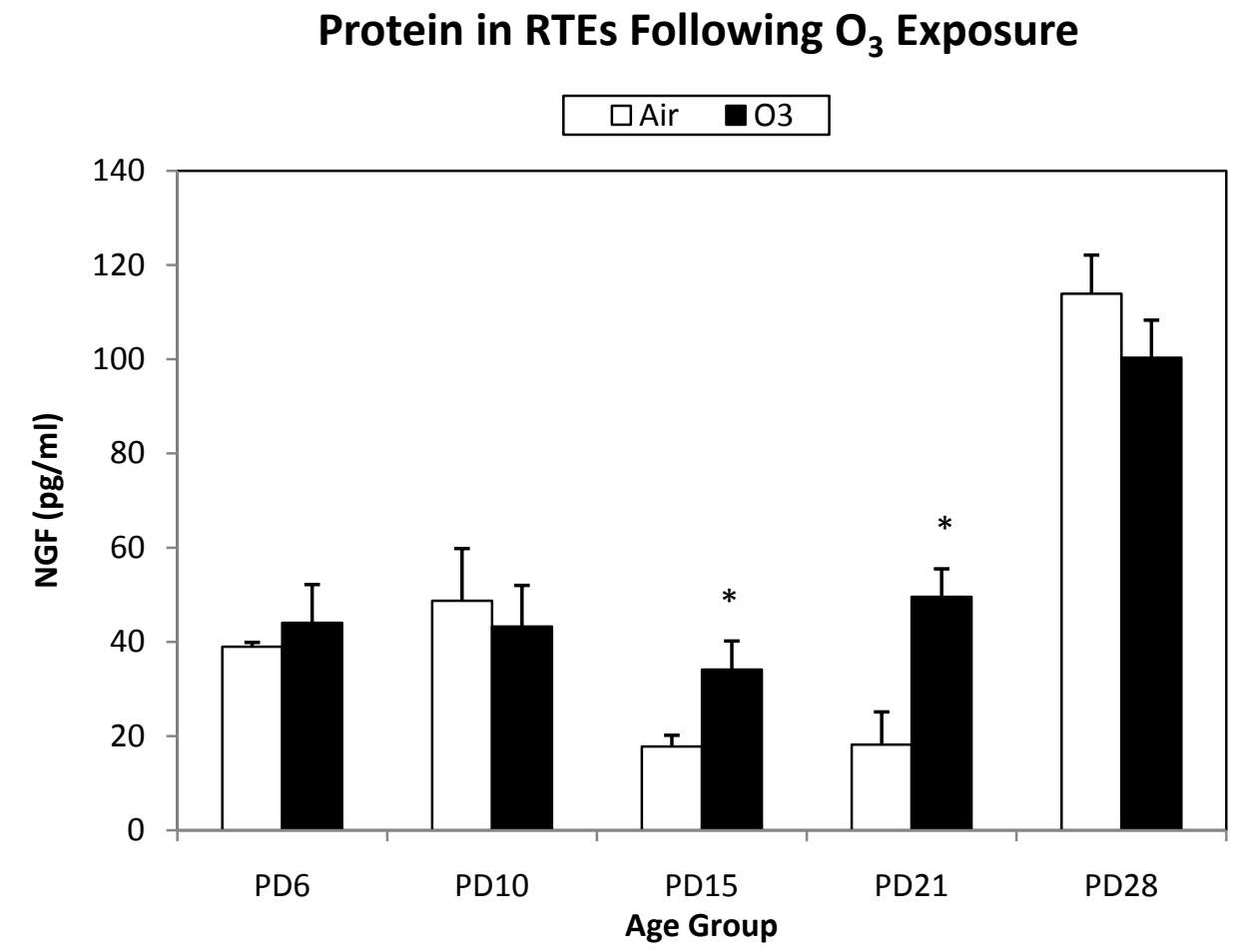

Figure 9. The effect of early postnatal $\mathrm{O}_{3}$ exposure on the amount of NGF protein in rat tracheal epithelial cells. NGF protein was measured in isolated rat tracheal epithelial cells 24 hours after exposure to determine if $\mathrm{O}_{3}$ exposure ( $2000 \mathrm{ppb}, 3$ hours) had an effect on the level of NGF in the cells. NGF protein was measured by ELISA. Values are means $\pm S E, n=6$ for each group and ${ }^{*} \mathrm{p}<0.05$ is significant compared to air control.

\section{NGF mRNA Expression during a Critical Period of Development}

To determine the effect of an early $\mathrm{O}_{3}$ exposure on subsequent exposures, a critical period paradigm was developed (see Figure 2). Rat pups were exposed to air or $\mathrm{O}_{3}$ on $\mathrm{PD} 6$ or PD 21. The pups were reexposed to either air or $\mathrm{O}_{3}$ on PD 28 and sacrificed 12 hours later. Control animals were exposed to air or $\mathrm{O}_{3}$ only on PD 28. The tracheal epithelial cells were extracted as described and NGF mRNA was measured using RT-PCR. NGF mRNA content in the PD 6 and $\mathrm{PD} 28 \mathrm{O}_{3}$ group $(2.02 \pm 0.10)$ was significantly higher than the $\mathrm{PD} 6 \mathrm{O}_{3}$ group not re-exposed at PD $28(1.14 \pm 0.19)$ and the PD 21 and PD 28 O3 group ((1.04 \pm 0.24$)$. The NGF expression of the $\mathrm{O}_{3}$ group exposed on PD 21 and PD 28 (1.04 \pm 0.24$)$ was not significantly 
different from the control ambient air group $(1.00 \pm 0.14)$ and the PD 28 only exposure group

$(0.78 \pm 0.11)$

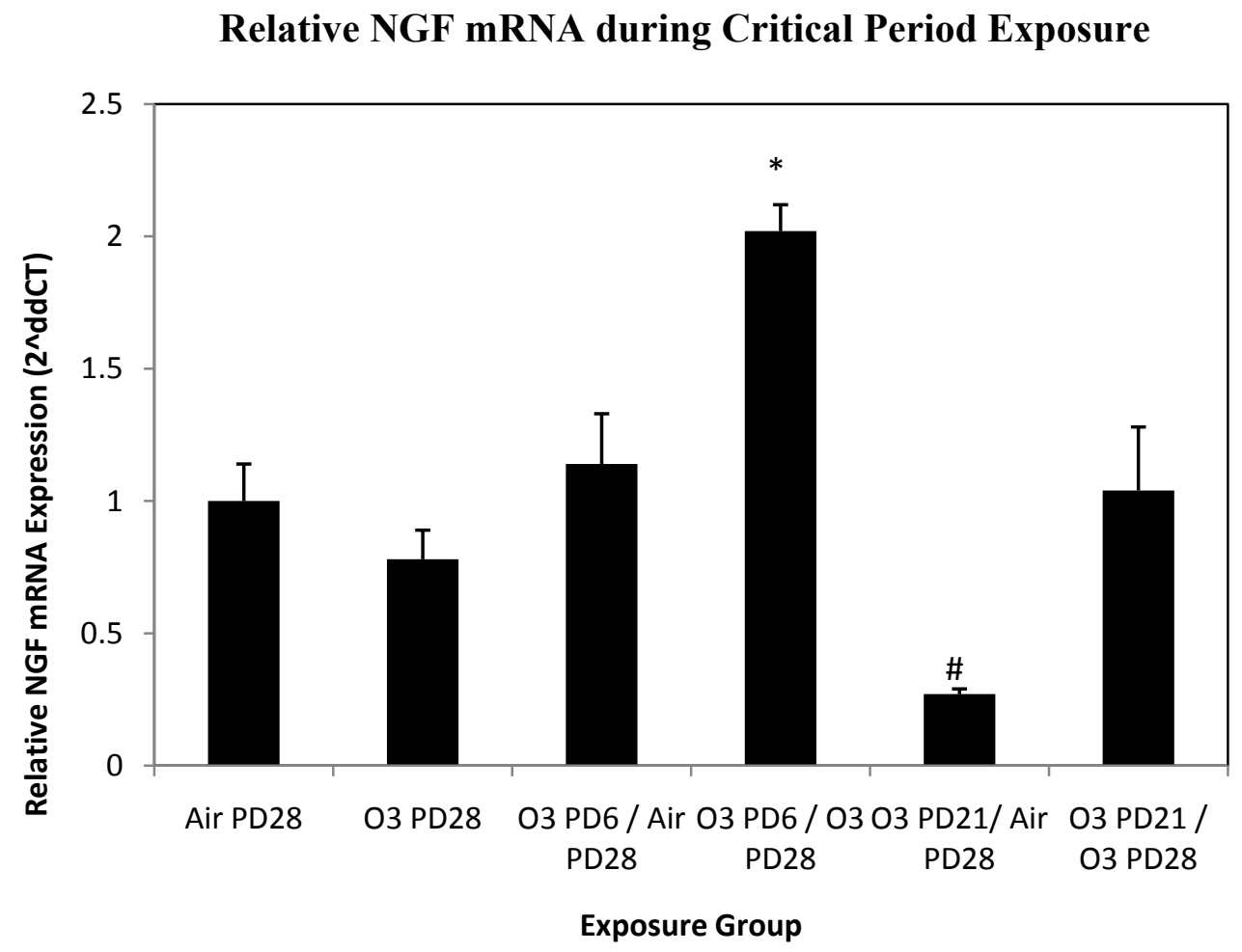

Figure 10. The effect of $\mathrm{O}_{3}$ exposure on relative NGF mRNA expression in tracheal epithelial cells during a critical period of development. NGF was measured to determine if $\mathrm{O}_{3}$ exposure (2000 ppb, 3 hours) during a critical period (PD 6) would result in prolonged changes of NGF message upon a second $\mathrm{O}_{3}$ exposure (PD 28) in comparison to controls and exposures outside the critical period (PD 21). NGF mRNA was measured by real-time PCR relative to $\beta$-actin mRNA expression. Values are means $\pm \mathrm{SE}, \mathrm{n}=6$ for each group and ${ }^{*} \mathrm{p}<0.05$ is significant compared to all groups, $\# \mathrm{p}<0.05$ is significant compared to all groups. 


\section{Discussion}

Exposure to ground-level $\mathrm{O}_{3}$ has been shown to decrease lung function, particularly in vulnerable populations, such as children (Tager et al., 2006). There are increasing concerns that the current EPA standard level of ambient $\mathrm{O}_{3}(75 \mathrm{ppb})$ is too high to prevent negative human health outcomes (Kim et al., 2011; Schelegle et al., 2009; World Health Organization, 2005). The epithelial cells that line the airway are the first point of contact for inhaled irritants, making the epithelium an important target for $\mathrm{O}_{3}$ injury. $\mathrm{O}_{3}$ is thought to modulate airway responses by upregulating the release of inflammatory mediators from airway epithelial cells (Bayram et al., 2001) which in turn alter epithelial cell function (Leikauf et al., 1995). NGF levels are increased in asthmatics (Bonini et al., 1996) and it is thought to play an important role in mediating asthma symptoms. Airway epithelial cells have been shown to produce NGF in response to inflammation (Fox et al., 2001). Increased NGF expression has been observed in patients with allergic inflammatory disease (Bresciani et al., 2009; Sanico et al., 2000) and asthma (Nassenstein et al., 2003; Bonini et al., 1996). NGF has also been shown to upregulate SP expression in C fiber neuronal cell bodies (Malcangio, 1997), increase airway innervation in mice (Hoyle et al., 1998) and induce airway hyperresponsiveness, a hallmark symptom of asthma (Quarcoo et al., 2004; Braun et al., 2001; Braun et al., 1999). Airway epithelial cells have been shown to produce and release NGF in response to inflammatory mediators (Hahn et al., 2006; Fox et al., 2001; Pons et al., 2001). The purpose of this study was to examine the production and release of NGF from tracheal epithelial cells following an acute $\mathrm{O}_{3}$ exposure during early postnatal life. $\mathrm{O}_{3}$ exposure is also known to cause an inflammatory response (Hernandez et al., 2010; Aris et al., 1993) and immune cells also produce NGF (Solomon et al., 1998; Noga et al., 2003; Rost et al., 2005). This study developed a novel method for measuring mRNA and protein levels in a population of 
isolated tracheal epithelial cells. The experiments used cells in which the immune cells were removed via anti-IgG antibody, resulting in a population of pure epithelial cells. The presence of epithelial cells was confirmed using fluorescent staining for cytokeratin. The presence of immune cells in cell populations with and without the anti-IgG antibody treatment was examined using a fluorescent CD45 antigen antibody. The cells treated with anti-IgG antibody showed a significant reduction in immune cells and enrichment of epithelial cells. Therefore, the results obtained show the effect of $\mathrm{O}_{3}$ exposure on the production of NGF in tracheal epithelial cells.

Because children appear to be a population that is especially susceptible to inhaled irritants, this study used an early postnatal $\mathrm{O}_{3}$ exposure model. Previous studies in our lab have shown an increase in SP nerve fiber density in the extrapulmonary epithelium and the intrapulmonary and extrapulmonary smooth muscle in rat pups exposed to $\mathrm{O}_{3}$ at PD 15 or earlier (Hunter et al., 2010a). In this study, rat pups were exposed to $\mathrm{O}_{3}$ (2000ppb for 3 hours) at PD 6, 10, 15, 21 or 28 and sacrificed 12 hours later to examine the effect of $\mathrm{O}_{3}$ on NGF mRNA in the tracheal epithelial cells. Animals were sacrificed 12 hours after exposure because this was the only time point to show a significant difference in NGF mRNA. This is consistent with other studies examining NGF mRNA production (Heumann et al., 1986; Barth et al., 1984). When compared to age-matched air controls, PD 6 rat pups showed a significant two-fold increase in the amount of NGF mRNA extracted from tracheal epithelial cells. Significant differences between air and $\mathrm{O}_{3}$ exposed animals were not observed at any other age. These results suggest that there is an early life sensitivity to $\mathrm{O}_{3}$ exposure with regard to epithelial cell interaction, as the earliest age examined was the only one to show a significant change in NGF mRNA.

To further examine the effect of early postnatal $\mathrm{O}_{3}$ exposure on tracheal epithelial cells, rat pups were exposed to $\mathrm{O} 3$ at $\mathrm{PD}$ 6, 10, 15, 21 or 28 and the level of NGF protein in the 
tracheal epithelial cells was measured 24 hours later, as previous work in our lab has shown an increase in SP nerve fiber density at 24 hours (Hunter et al., 2010a). The early life exposure to $\mathrm{O}_{3}$ did not lead to an increase in NGF in the isolated rat tracheal epithelial cells at PD 6. It did, however, lead to an increase in NGF at both PD 15 and PD 21. These experiments measured the levels of NGF within the tracheal epithelial cells following an airway irritant exposure. It is possible that the amount of NGF was increased following the $\mathrm{O}_{3}$ exposure at earlier postnatal days and that this NGF was released from the cells, and therefore not measurable in this set of experiments. The increased NGF protein at PD 15 and PD 21 suggests that this protein was sequestered in the cells and not released at these postnatal ages, but previous work has shown an increase in NGF in bronchoalveolar lavage fluid following an $\mathrm{O}_{3}$ exposure at PD 10 and PD 15 (Hunter et al, 2010b). As bronchoalveolar lavage fluid measures the total protein in the lung, it is possible that the NGF measurements obtained in that study reflect the contribution of immune cells. Further experiments, potentially in vitro, measuring the amount of NGF released from tracheal epithelial cells would provide more information regarding this possible phenomenon.

The increase in NGF mRNA in tracheal epithelial cells at PD 6 did not directly produce an increase in NGF protein. Likewise, the lack of an NGF mRNA increase at PD 15 and PD 21 did not prevent the increase of NGF protein. It is possible that the timing of NGF mRNA production changes with development and that measuring the mRNA at other time points after exposure would have shown an increase in NGF mRNA. It is also possible that the protein was increased at PD 6 and was released from the cells prior to cell extraction and measurement. NGF is produced and secreted, not stored in cells and released on demand (Heumann et al., 1984; Shelton \& Reichardt, 1984), so it is possible that the increase in NGF protein occurred at an earlier time point. 
Further studies were completed to examine how the effect an $\mathrm{O}_{3}$ exposure during this early critical or sensitive period of development ( $\leq$ PD 6 ) might affect the response to a second exposure later in life ( $\geq$ PD 28). Previous work in our lab has shown that rat pups exposed to $\mathrm{O}_{3}$ during the critical period show an increase in SP nerve fiber density following a second $\mathrm{O}_{3}$ exposure outside of the critical period (Hunter et al., 2010a). This effect was not observed when rat pups were initially exposed outside of the critical period or when the initial exposure was followed by an air exposure in later life. The NGF measured in broncoalveolar lavage is also significantly increased in rat pups exposed to $\mathrm{O}_{3}$ on both PD 6 and PD 28 (Hunter et al., 2010b). The results of the current study correlate with the previous findings. Rat pups were exposed to $\mathrm{O}_{3}$ within (PD 6) or beyond (PD 21) the proposed critical period. A second exposure to $\mathrm{O}_{3}$ or air occurred on PD 28. Rat pups that were exposed to $\mathrm{O}_{3}$ on both PD 6 and PD 28 showed a significant increase in NGF mRNA in the tracheal epithelial cells. Rat pups that were initially exposed to $\mathrm{O}_{3}$ on PD 21 or that were exposed to $\mathrm{O}_{3}$ on PD 6 and air on PD 28 did not show any significant change in NGF mRNA from control. The results of this series of experiments suggest a critical period of development during which younger animals are more susceptible to the effects of airway irritants and that this early life exposure could have an effect on the response to later exposures.

The critical period experiments show that the effect of ozone-exposure during the period of early life sensitivity can persistent and have an effect on the response to exposures in later life. These results suggest a novel NGF pathway that contributes to early life sensitivity to inhaled irritants. NGF has been shown to upregulate SP expression in airway nerves (Larsen et al., 2004) through both the TrkA and p75 neurotrophin receptors (Skoff et al., 2006). In guinea pigs, NGF administration increases airway hyperresponsiveness through neurokinin-1 (NK-1), a SP receptor 
(de Vries et al., 1999). Increased SP expression has also been shown to increase blood vessel extravasation by binding to endothelial cell NK-1 receptors (Li et al., 2008). Airway hyperresponsiveness and edema are hallmark symptoms of asthma (Bergeron et al., 2010) and these results show a possible role for NGF from tracheal epithelial cells in mediating this asthma symptom. Furthermore, NGF could support the proliferation or branching of nerves in the airway smooth muscle that are typically pruned during development. NGF is known to promote sensory nerve growth and survival (Levi-Montalcini, 1987) and mice that overexpress NGF display increased airway sensory innervation (Hoyle et al., 1998). The increase in NGF in tracheal epithelial cells following an early life O3 exposure might therefore promote innervation. The increase in sensory innervation could lead to increased sensitivity in later responses to $\mathrm{O}_{3}$ exposure. NGF release plays a role in the recruitment, survival, and activation of inflammatory cells (Freund \& Frossard, 2004). The NGF released by tracheal epithelial cells in response to $\mathrm{O}_{3}$ might therefore contribute to airway inflammation. As proinflammatory cytokines are known to upregulate the release of NGF from airway structural cells, including epithelial cells (Fox et al., 2001), the initial release of NGF from tracheal epithelial cells might lead to a secondary increase in NGF production through inflammation (Leikauf et al., 1995). Blocking the initial increase in NGF could be an important step in reducing the response to airway irritants.

Future studies examining the potential role for NGF in the response to airway irritants need to be conducted. Knocking down or preventing the observed increase in NGF and then measuring SP expression in the airways would show whether or not the increase in NGF leads to the increased SP observed in airway sensory neurons following an $\mathrm{O}_{3}$ exposure. Currently, there are no selective NGF antagonists that could be used to perform these important studies, but the use of an NGF siRNA could provide more information about NGF's role in the $\mathrm{O}_{3}$ response. 
Further studies could look at the possible role of other neurotrophins, such as brain-derived neurotrophic factor (BDNF), in the response to airway irritants. BDNF has also been shown to be upregulated in asthmatics and associated with clinical severity of asthma symptoms (Lommatzch et al., 2005; Muller et al., 2010). Functional studies examining the role of neurotrophins in response to inhaled irritants are also necessary for a more complete understanding of the clinical significance of these findings. 


\section{Reference List}

Adler, J. E., Kessler, J. A., \& Black, I. B. (1984). Development and regulation of substance P in sensory neurons in vitro. Developmental Biology, 102(2), 417-425.

Akinbami, L.J. \& Schoendorf, K.C. (2002). Trends in Childhood Asthma: Prevalence, Health Care Utilization, and Mortality. Pediatrics, 110, 315-322.

Aris, R.M., Christian, D., Hearne, P.Q., Kerr, K., Finkbeiner, W.W., Balmes, J.R. (1993). Ozone-induced airway inflammation in human subjects as determined by airway lavage and biopsy. Am Rev Respir Dis., 148(5):1363-1372.

Bennedich Kahn, L., Gustafsson, L. E., \& Olgart Höglund, C. (2008). Brain-derived neurotrophic factor enhances histamine-induced airway responses and changes levels of exhaled nitric oxide in guinea pigs in vivo. European Journal of Pharmacology, 595(13), 78-83.

Bergeron, C., Tulic, M.K., Hamid, Q. (2010) Airway remodelling in asthma: from benchside to clinical practice. Can Respir J, 17(4), e85-93.

Blomberg, A., Mudway, I.S., Nordenhall, C., Hedenstrom, H., Kelly, F.J, Frew, A.J., Holgate, S.T., \& Sandstrom, T. (1999). Ozone-induced lung function decrements do not correlate with early airway inflammatory or antioxidant responses. Eur Respir J, 13(6), 1418-1428.

Bonini, S., Lambiase, A., Bonini, S., Angelucci, F., Magrini, L., \& Aloe, L. (1996). Circulating nerve growth factor levels are increased in humans with allergic diseases and asthma. Proc. Natl. Acad. Sci. USA., 93(20), 10955-10960.

Bresciani, M., Laliberte, F., Laliberte, M.F., Gramiccioni, C., Bonini, S. (2009). Nerve growth factor localization in the nasal mucosa of patients with persistent allergic rhinitis. Allergy, 64(1):112-117.

Braun, A., Quarcoo, D., Schulte-Herbrüggen, O., Lommatzsch, M., Hoyle, G., Renz, H. (2001). Nerve growth factor induces airway hyperresponsiveness in mice. Int Arch Allergy Immunol. 124(1-3):205-207.

Braun, A., Lommatzsch, M., Lewin, G.R., Virchow, J.C., Renz, H. (1999). Neurotrophins: a link between airway inflammation and airway smooth muscle contractility in asthma? Int Arch Allergy Immunol., 118(2-4):163-165.

Bruno, M.A. \& Cuello, A.C. (2006). Activity-dependent release of precursor nerve growth factor, conversion to mature nerve growth factor, and its degradation by a protease cascade. Proc. natl. Acad. Sci. USA, 103(17), 673-674. 
de Vries, A., Dessing, M.C., Engels, F., Henricks, P.A., Nijkamp, F.P. (1999) Nerve growth factor induces a neurokinin-1 receptor- mediated airway hyperresponsiveness in guinea pigs. Am J Respir Crit Care Med., 159(5 Pt 1):1541-1544.

Dey, R. D., Satterfield, B., \& Altemus, J. B. (1999). Innervation of tracheal epithelium and smooth muscle by neurons in airway ganglia. The Anatomical Record, 254(2), 166-172.

Donkin, J. J., Turner, R. J., Hassan, I., \& Vink, R. (2007). SP in traumatic brain injury. Progress in Brain Research, 161, 97-109.

Fischer, A., McGregor, G. P., Saria, A., Philippin, B., \& Kummer, W. (1996). Induction of tachykinin gene and peptide expression in guinea pig nodose primary afferent neurons by allergic airway inflammation. The Journal of Clinical Investigation, 98(10), 2284-2291. doi: 10.1172/JCI119039.

Fontan, J. J. P., Cortright, D. N., Krause, J. E., Velloff, C. R., Karpitskyi, V. V., Carver, T. W., et al. (2000). SP and neurokinin-1 receptor expression by intrinsic airway neurons in the rat. Am J Physiol Lung Cell Mol Physiol, 278(2), L344-355.

Forgie, A., Kuehnel, F., Wyatt, S., \& Davies, A. M. (2000). In vivo survival requirement of a subset of nodose ganglion neurons for nerve growth factor. The European Journal of Neuroscience, 12(2), 670-676.

Fox, A.J.; Patel, H.J.; Barnes, P.J.; Belvisi, M.G. (2001). Release of nerve growth factor by human pulmonary epithelial cells: role in airway inflammatory diseases. Eu J. Pharmacol. 424(2):159-162.

Frampton, M.W., Morrow, P.E., Torres, A., Voter, K.Z., Whitin, J.C., Cox, C., Speers, D.M., Tsai, Y., \& Utell, M.J. (1997a). Effects of ozone on normal and potentially sensitive human subjects. Part I: Airway inflammation and responsiveness to ozone in normal and asthmatic subjects. Res Rep Health Eff Inst, 78, 1-37.

Frampton, M.W., Morrow, P.E., Torres, A., Voter, K.Z., Whitin, J.C., Cox, C., Speers, D.M., Tsai, Y., \& Utell, M.J. (1997b). Effects of ozone on normal and potentially sensitive human subjects. Part II: Airway inflammation and responsiveness to ozone in nonsmokers and smokers. Res Rep Health Eff Inst, 78, 39-72.

Freund, V., \& Frossard, N. (2004). Expression of nerve growth factor in the airways and its possible role in asthma. Progress in Brain Research, 146, 335-346.

Gent, J. F., Triche, E. W., Holford, T. R., Belanger, K., Bracken, M. B., Beckett, W. S., et al. (2003). Association of low-level O3 and fine particles with respiratory symptoms in children with asthma. JAMA: The Journal of the American Medical Association, 290(14), 1859-1867. doi: 10.1001/jama.290.14.1859.

Gerard, N. P., Garraway, L. A., Eddy, R. L., Shows, T. B., Iijima, H., Paquet, J. L., et al. (1991). Human SP receptor (NK-1): organization of the gene, chromosome localization, and functional expression of cDNA clones. Biochemistry, 30(44), 10640-10646. 
Hahn, C., Islamian, A. P., Renz, H., \& Nockher, W. A. (2006). Airway epithelial cells produce neurotrophins and promote the survival of eosinophils during allergic airway inflammation. Journal of Allergy and Clinical Immunology, 117(4), 787-794. doi: 10.1016/j.jaci.2005.12.1339.

Hernandez, M.L, Harris, B., Lay, J.C., Bromber, P.A. Diaz-Sanchez, D., Devlin, R.B., Kleeberger, S.R., Alexis, N.E., \& Peden, D.B. (2010). Comparative airway inflammatory response of normal volunteers to ozone and lipopolysaccharide challenge. Inhal Toxicol, 22(8), 648-656.

Hernández-Cadena, L., Barraza-Villarreal, A., Ramírez-Aguilar, M., Moreno-Macías, H., Miller, P., Carbajal-Arroyo, L. A., et al. (2007). Infant morbidity caused by respiratory diseases and its relation with the air pollution in Juarez City, Chihuahua, Mexico. Salud Pública De México, 49(1), 27-36.

Heumann, R., Korsching, S., Scott, J., Thoenen, H. (1984). Relationship between levels of nerve growth factor (NGF) and its messenger RNA in sympathetic ganglia and peripheral target tissues. EMBO J., 3(13):3183-3189.

Heumann, R., Thoenen, H. (1986). Comparison between the time course of changes in nerve growth factor protein levels and those of its messenger RNA in the cultured rat iris. $J$ Biol Chem., 261(20):9246-9249.

Hoyle, G.W., Graham, R.M., Finkelstein, J.B., Nguyen, K.P., Gozal, D., \& Friedman, M. (1998). Hyperinnervation of the Airways in Transgenic Mice Overexpressing Nerve Growth Factor. Am. J. Respir. Cell Mol. Biol., 18(2), 149-157.

Hunter, D.D., Wu, Z., \& Dey, R.D. (2010a). Sensory neural responses to ozone exposure during early postnatal development in rat airways. Am J Respir Cell Mol Biol, 43(6), 750-757.

Hunter, D.D., Carrell-Jacks, L.A., Batchelor, T.P., Dey, R.D. (2010b). Role of Nerve Growth Factor in Ozone-Induced Neural Responses in Early Postnatal Airway Development. Am J Respir Cell Mol Biol. [Epub ahead of print].

Kafoury, R. M., \& Kelley, J. (2005). O3 enhances diesel exhaust particles (DEP)-induced interleukin-8 (IL-8) gene expression in human airway epithelial cells through activation of nuclear factors- kappaB (NF-kappaB) and IL-6 (NF-IL6). International Journal of Environmental Research and Public Health, 2(3-4), 403-410.

Kessler, J. A., \& Black, I. B. (1980). Nerve growth factor stimulates the development of SP in sensory ganglia. Proceedings of the National Academy of Sciences of the United States of America, 77(1), 649-652.

Khansaheb, M., Choi, J.Y., Joo, N.S., Yang, Y.M., Krouse, M., \&Wine, J.J. (2011). Properties of substance P-stimulated mucus secretion from porcine tracheal submucosal glands. Am J Physiol Lung Physiol, 300(3), 370-379. 
Kim, C.S., Alexis, N.E., Rappold, A.G., Kehrl, H., Hazucha, M.J., Lay, J.C., Schmitt, M.T., Case, M., Devlin, R.B., Peden, D.B., \& Diaz-Sanchez, D. (2011). Lung function and inflammatory responses in healthy young adults exposed to $0.06 \mathrm{ppm}$ ozone for 6.6 hours. Am J Respir Crit Care Med, Epub ahead of print.

Koto, H., Aizawa, H., Takata, S., Inoue, H., \& Hara, N. (1995). An important role of tachykinins in O3-induced airway hyperresponsiveness. Am. J. Respir. Crit. Care Med., 151(6), 1763-1769.

Krishna, M.T., Madden, J., Teran, L.M., Biscione, G.L., Lau, L.C., withers, N.J., Sandstrom, T., Mudway, I, Kelly, F.J., Walls, A., Frew, A.J., \& Holgate, S.T. (1998). Effects of 0.2 ppm ozone on biomarkers of inflammation in blronchoalveolar lavage fluid and bronchial mucosa of healthy subjects. Eur Respir J, 11(6), 1294-1300.

Larsen, G.L., Loader, J., Nguyen, D.D., Fratelli, C., Dakhama, A., \& Colasurdo, G.N. (2004). Mechanisms determining cholinergic neural responses in airways of young and mature rabbits. Pediatr Pulmonol, 38(2), 97-106.

Leikauf, G.D., Simpson, L.G., Santrock, J., Zhao, Q., Abbinante-Nissen, J., Zhou, S., \& Driscoll, K.E. (1995). Airway epithelial cell responses to O3 injury. Environ Health Perspect, 103(2), 91-95.

Lembeck, F., \& Holzer, P. (1979). SP as neurogenic mediator of antidromic vasodilation and neurogenic plasma extravasation. Naunyn-Schmiedeberg's Archives of Pharmacology, 310(2), 175-183. doi: 10.1007/BF00500282.

Lewis, T. C., Robins, T. G., Dvonch, J. T., Keeler, G. J., Yip, F. Y., Mentz, G. B., et al. (2005). Air pollution-associated changes in lung function among asthmatic children in Detroit. Environmental Health Perspectives, 113(8), 1068-1075.

Li, P.C., Chen, W.C., Chang, L.C., \& Lin, S.C. (2008). Substance P acts via the neurokinin receptor 1 to elicit bronchoconstriction, oxidative stress, and upregulated ICAm-1 expression after oil smoke exposure. Am J Physiol Lung Cell Mol Physiol, 294(5), L912L920.

Lommatzsch, M., Schloetcke, K., Klotz, J., Schuhbaeck, K., Zingler, D., Zingler, C., SchulteHerbruggen, O., Gill, H., Schuff-Werner, P, \& Virchow, J.C. (2005). Brian-derived neurotrophic factor in platelets and airflow limitation in asthma. Am. J. Respir. Crit. care Med., 171(2), 115-120.

Malcangio M, Garrett NE, Tomlinson DR. (1997). Nerve growth factor treatment increases stimulus-evoked release of sensory neuropeptides in the rat spinal cord. Eur J Neurosci., 9(5):1101-4. 
Meyer, M., Matsuoka, I., Wetmore, C., Olson, L., \& Thoenen, H. (1992). Enhanced synthesis of brain-derived neurotrophic factor in the lesioned peripheral nerve: different mechanisms are responsible for the regulation of BDNF and NGF mRNA. J. Cell. Biol., 119(1), 4554.

Miller, L. A., Gerriets, J. E., Tyler, N. K., Abel, K., Schelegle, E. S., Plopper, C. G., et al. (2009). $\mathrm{O} 3$ and allergen exposure during postnatal development alters the frequency and airway distribution of CD25+ cells in infant rhesus monkeys. Toxicology and Applied Pharmacology, 236(1), 39-48. doi: 10.1016/j.taap.2008.12.031.

Miller, M. S., Buck, S. H., Sipes, I. G., Yamamura, H. I., \& Burks, T. F. (1982). Regulation of SP by nerve growth factor: disruption by capsaicin. Brain Research, 250(1), 193-196.

Molliver, D. C., \& William D. Snider. (1997). Nerve growth factor receptor trkA is downregulated during postnatal development by a subset of dorsal root ganglion neurons. The Journal of Comparative Neurology, 381(4), 428-438. doi: 10.1002/(SICI)10969861(19970519)381:4<428::AID-CNE3>3.0.CO;2-4.

Muller, G.C., Pitrez, P.M., Teixeira, A.L., Pires, P.S., Jones, M.H., Stein, R.T., \& Bauer, M.E. (2010). Plasma brainderived neurotrophic factor levels are associated with clinical severity in school age children with asthma. Clin Exp allergy, 40(12), 1755-1759.

Nassenstein, C., Braun, A., Erpenbeck, V. J., Lommatzsch, M., Schmidt, S., Krug, N., et al. (2003). The neurotrophins nerve growth factor, brain-derived neurotrophic factor, neurotrophin-3, and neurotrophin-4 are survival and activation factors for eosinophils in patients with allergic bronchial asthma. The Journal of Experimental Medicine, 198(3), 455-467. doi: 10.1084/jem.20010897.

Noga, O., G. Hanf, C. Sch per, A. O'Connor, \& G. Kunkel. (2001). The influence of inhalative corticosteroids on circulating Nerve Growth Factor, Brain-Derived Neurotrophic Factor and Neurotrophin-3 in allergic asthmatics. Clinical \& Experimental Allergy, 31(12), 1906-1912. doi: 10.1046/j.1365-2222.2001.01249.x.

Noga, O., Englmann, C., Hanf, G., Grutzkau, A., Seybold, J., \&Kunkel, G. (2003). The production, storage and release of the neurotrophins nerve growth factor, brain-derived neurotorphic factor and neurotrophin-3 by human peripheral eosinophils in allergics and non-allergics. Clin Exp allergy, 33(5), 649-654.

Ollerenshaw, S., Jarvis, D., Sullivan, C., \& Woolcock, A. (1991). SP immunoreactive nerves in airways from asthmatics and nonasthmatics. Eur Respir J, 4(6), 673-682.

Oslund, K. L., Hyde, D. M., Putney, L. F., Alfaro, M. F., Walby, W. F., Tyler, N. K., et al. (2008). Activation of neurokinin-1 receptors during O3 inhalation contributes to epithelial injury and repair. American Journal of Respiratory Cell and Molecular Biology, 39(3), 279-288. doi: 10.1165/rcmb.2008-0009OC.

Otten, U., Goedert, M., Mayer, N., \& Lembeck, F. (1980). Requirement of nerve growth factor for development of SP-containing sensory neurones. Nature, 287(5778), 158-159. doi: $10.1038 / 287158 \mathrm{a} 0$. 
Plopper, C. G., Smiley-Jewell, S. M., Miller, L. A., Fanucchi, M. V., Evans, M. J., Buckpitt, A. R., et al. (2007). Asthma/allergic airways disease: does postnatal exposure to environmental toxicants promote airway pathobiology? Toxicologic Pathology, 35(1), 97110. doi: 10.1080/01926230601132030.

Pons, F; Freund, V; Kuissu, H; Mathieu, E; Olgart, C; Frossard, N. (2001) Nerve growth factor secretion by human lung epitheial A549 cells in pro- and anti-inflammatory conditions. Eu J Pharmacol. 428(3):365-369.

Quarcoo, D., Schulte-Herbrüggen, O., Lommatzsch, M., Schierhorn, K., Hoyle, G.W., Renz, H., Braun, A. (2004). Nerve growth factor induces increased airway inflammation via a neuropeptide-dependent mechanism in a transgenic animal model of allergic airway inflammation. Clin Exp Allergy., 34(7):1146-1151.

Rost, B., Hanf, G., Ohnemus, U., Otto-Knapp, R., Groneberg, D.A., Kunkel, G., \& Noga, O. (2005). Monocytes of allergics and non-allergics produce, store and release the neurotrophins NGF, BDNF and NT-3. Regul Pept, 124(1-3), 19-25.

Sanico, A.M., Stanisz, A.M., Gleeson, T.D., Bora, S., Proud, D., Bienenstock, J., Koliatsos, V.E., Togias, A. (2000). Nerve growth factor expression and release in allergic inflammatory disease of the upper airways. Am J Respir Crit Care Med., 161(5):1631-1635.

Schelegle, E.S., Morales, C.A., Walby, W.F., Marion, S., Allen, R.P. (2009). 6.6-hour inhalation of ozone concentrations from 60 to 87 parts per billion in healthy humans. Am J Respir Crit Care Med., 180(3):265-272.

Schwartz, J. P., Pearson, J., \& Johnson, E. M. (1982). Effect of exposure to anti-NGF on sensory neurons of adult rats and guinea pigs. Brain Research, 244(2), 378-381.

Shelton, D.L., Reichardt, L.F. (1984). Expression of the beta-nerve growth factor gene correlates with the density of sympathetic innervation in effector organs. Proc Natl Acad Sci U S A., 81(24):7951-5.

Skoff AM, Adler JE. (2006). Nerve growth factor regulates substance P in adult sensory neurons through both TrkA and p75 receptors. Exp Neurol., 197(2):430-6.

Solomon, A., Aloe, L., Pe'er, J., Frucht-Pery, J., Bonini, S., Bonini, S., \& Levi-Schaffer, F. (1998). Nerve growth factor is preformed in and activates human peripheral blood eosinophils. J Allergy Clin Immnol, 102(3), 454-460.

Sterner-Kock, A., Kock, M., Braun, R., \& Hyde, D.M. (2000) O3-induced epithelial injury in the ferret is similar to nonhuman primates. Am. J. Respir. Crit. Care Med., 162, 1152-1156.

Tager, I.B., Balmes, J., Lurmann, F., Ngo, L., Alcorn, S., Künzli, N. (2005). Chronic exposure to ambient ozone and lung function in young adults. Epidemiology., 16(6):751-9. 
Wilfong, E. R., \& Dey, R. D. (2004). Nerve Growth Factor and SP Regulation in Nasal Sensory Neurons after Toluene Diisocyanate Exposure. Am. J. Respir. Cell Mol. Biol., 30(6), 793800. doi: 10.1165/rcmb.2003-0303OC.

Woolf, C. J., Safieh-Garabedian, B., Ma, Q. P., Crilly, P., \& Winter, J. (1994). Nerve growth factor contributes to the generation of inflammatory sensory hypersensitivity. Neuroscience, 62(2), 327-331.

Wu, Z., \& Dey, R. D. (2006). Nerve growth factor-enhanced airway responsiveness involves SP in ferret intrinsic airway neurons. Am J Physiol Lung Cell Mol Physiol, 291(1), L111118.

Wu, Z., \& Lee, L. (1999). Airway hyperresponsiveness induced by chronic exposure to cigarette smoke in guinea pigs: role of tachykinins. J Appl Physiol, 87(5), 1621-1628. 


\section{Lynnsey A. Carrell-Jacks}

Department of Neurobiology \& Anatomy

P.O. Box 9128 Health Sciences North

West Virginia University

Morgantown, WV 26506

Office: (304) 293-0596

Fax: (304) 293-8159

E-mail: lynnsey.carrell@gmail.com

\section{Education}

West Virginia University, Morgantown, WV

- Master of Science, Biomedical Sciences In Progress

West Virginia University, Morgantown, WV

- Bachelor of Science, Biology 2006

- Bachelor of Science, Psychology 2006

- Minor: English

\section{Meetings and Presentations}

Carrell-Jacks, L.A., Dey, R.D., Hunter, D.D. (2010). O3-Induced Nerve Growth Factor Expression in Rat Airway Epithelium During a Critical Period of Early Postnatal Development. ATS, New Orleans, LA.

Carrell-Jacks, L.A., Rogers-Nieman, G.M., Hunter, D.D. (2009). O3 Induces Nerve Growth Factor Expression in Tracheal Epithelial Cells in Early Postnatal Life. Experimental Biology, New Orleans, LA.

Carrell-Jacks, L.A., Rogers-Nieman, G.M., Hunter, D.D. (2009). O3 Induces Nerve Growth Factor Expression in Tracheal Epithelial Cells in Early Postnatal Life. Van Liere Research Convocation, Morgantown, WV.

Carrell, L.A., Dey, R.D., Hunter, D.D., Batchelor, T.P. (2008). NFATc2 and NFATc3 Localization in VIP Knock-Out Mice. Van Liere Research Convocation, Morgantown, WV.

Carrell, L.A., Dey, R.D., Hunter, D.D., Batchelor, T.P. (2008). NFATc2 and NFATc3 Localization in VIP Knock-Out Mice. Neuroscience Retreat, Wheeling, WV.

\section{Publications}

Hunter, D.D., Carrell-Jacks, L.A., Batchelor, T.P., \& Dey, R.D. (2010). Role of Nerve Growth Factor in O3-induced neural responses in early postnatal airway development. Am J Respir Cell Mol Biol. PMID: 21075861 
Daly, K.C., Carrell, L.A., \& Mwilaria, E. (2008). Characterizing psychophysical measures of discrimination thresholds and the effects of concentration on discrimination learning in the moth Manduca sexta. Chem Senses. 33(1):95-106. PMID: 17663604

Daly, K.C., Carrell, L.A., \& Mwilaria, E. (2007). Detection versus perception: physiological and behavioral analysis of olfactory sensitivity in the moth (Manduca sexta). Behav Neurosci. 121(4):794-807. PMID: 17928636 
OZONE INDUCES NERVE GROWTH FACTOR RELEASE FROM RAT TRACHEAL EPITHELIAL CELLS DURING AN EARLY POSTNATAL CRITICAL PERIOD

Lynnsey A. Carrell-Jacks

Thesis submitted to the School of Medicine

at West Virginia University

in partial fulfillment of the requirements

for the degree of

Master of Science

In

Biomedical Sciences

Department of Neurobiology and Anatomy

APPROVAL OF THE EXAMINING COMMITTEE

Dawn D. Hunter, Ph.D.

Gregory W. Konat, Ph.D.

Date

Richard D. Dey, Ph.D., Chair

John H. 